\title{
Orta Asya Ülkelerinde ve Türkiye'de Devletin Rolüne İlişkin Tutumlar ${ }^{*}$
}

\section{Savaş Çevik $^{* *}$}

Öz

Çalışma devletin rolüne ilişkin tutumlardaki farklılıkları ülkeler arasında karşlaştırmayı ve bireysel düzeyde yeniden dağılım ve kamu mülkiyetine dair tercihlerin belirleyicilerini, WVS ve EVS verilerine dayanarak, Orta Asya Ülkeleri ve Türkiye için karşılaştırmalı olarak analiz etmeyi amaçlamıştır. Ülkeler arasında karşılaştırma zaman boyutunda devletin rolü lehine eğilimin birçok ülke grubunda arttığını göstermektedir. Bir diğer önemli olgu devlet-piyasa karşıtllğı çerçevesindeki tutumların ülkelerin gelir seviyesi ile de ilişkili olduğudur. Yeniden dağılım yanlısı tutum kişibaşı gelirle pozitif, kamu mülkiyeti, devlet sorumluluğu yanlısı görüşlerin negatif birlikteliğe sahip bulunmuştur. Ülke içinde tutumlarda homojenlik ülkede kişibaşı gelir yükselirken artmaktadır. Orta Asya Ülkeleri ve Türkiye'de yeniden dağılım ve kamu mülkiyetine ilişkin görüşlerin bireysel düzeyde belirleyicileri, tüm örneklem için ve ayrı ayrı ülke örneklemleri için regresyonlar aracilğ̆ıyla analiz edilmiştir. Sonuçlar demografik karakteristiklerin yanı sıra, gelirin, sübjektif refahın, güvenin, siyasal görüşlerin ve dindarlığın devletin rolüne ilişkin tercihlerin önemli belirleyicileri olduğunu göstermiştir. Ancak bu değişkenlerin önemi ülkeler arasında farklıdır.

\section{Anahtar Kelimeler}

Yeniden dağılım, siyasal tercihler, refah devleti, sosyal güven, Orta Asya, devletin rolü.

\footnotetext{
Geliş Tarihi: 09 Şubat 2017 - Kabul Tarihi: 07 Haziran 2017 Bu makaleyi şu şekilde kaynak gösterebilirsiniz: Çevik, Savaş (2019). “Orta Asya Ülkelerinde ve Türkiye'de Devletin Rolüne İlişkin Tutumlar”. bilig Türk Dünyası Sosyal Bilimler Dergisi 91: 81-112.

** Doç. Dr., Selçuk Üniversitesi, İktisadi ve İdari Bilimler Fakültesi, İktisat Bölümü - Konya/Türkiye ORCID ID: https://orcid.org/0000-0003-0730-0746 scevik@selcuk.edu.tr
} 


\section{Giriş}

Bir ekonomide devletin ve piyasanın görece rollerinin, sınırlarının ve işlevlerinin ne olması gerektiği iktisat ve siyaset felsefesinde önemli bir tartışma konusudur. Akademik tartışmalarda konuya dair fikir ayrılıkları ve tartışmalar bulunuyor olmasına rağmen uygulamada bazı ortak eğilimler gözlemlenebilmektedir. Özellikle 1980'lerden sonra çoğu dünya ülkesinde izlenebilecek ortak bir eğilim boyut olarak devleti küçültmek, piyasa üzerindeki müdahalelerini azaltmak ve yeniden dağıtıcı işlevlerini sınırlamak yönünde ekonomik ve yönetimsel reformlar izlemek olmuştur. Bu reform eğilimlerinin temelinde toplumsal kaynakların tahsisinde piyasanın devletten daha etkin bir mekanizma olduğuna dair kabul yatmaktadır.

Bu kabul 1990'ların başında Sovyetler Birliğinin dağılmasıyla daha da kuvvetlenmiştir. Sosyalist ideolojinin uygulamalarının çöküşü ile gerek bağımsız olan yeni devletler gerekse zaten bağımsız olan sosyalist ülkelerde merkezi planlamadan serbest piyasa ekonomisine geçiş amacı taşıyan kapsamlı reformlara girişilmiştir. Bu çalışmanın ilgisini oluşturan Orta Asya ülkeleri de Sovyetler Birliği ile sıkı entegre olmuş, bu yönde reformlar yapan geçiş ekonomilerindendir. Bu ülkelerde yapılan reformlar sadece basitçe devleti küçültmenin ötesinde piyasa mantığını yerleştirmek, devletle vatandaşlar arasındaki mali, ekonomik ve politik ilişkileri de dönüştürmek, bir anlamda yeni bir toplum sözleşmesi inşa etmek unsurları içermektedir.

Kuşkusuz geçiş ekonomilerindeki reformlar farklı ülkelerde farklı sonuçlar üretmiştir. Her şeyden önce bu ülkeler başlangıç koşulları açısından farklıdır. Diğer geçiş ekonomileri ile karşılaştırıldığında Orta Asya ülkeleri Sovyet sistemine sıkı entegre olmuş bulunmak, ortak bir tarihsel/kültürel mirası paylaşmak ve derin bir piyasa deneyimi bulunmamak ve yetersiz sanayileşme gibi ortak bazı özelliklere sahiptir. Ancak Orta Asya ülkeleri arasında da bir çeşitlilikten söz edilebilir. Sözgelimi Azerbaycan ve Kazakistan doğal kaynak zengini iken Kırgızistan ve Özbekistan bu açıdan fakirdir. Kırgızistan geçiş öncesinde tarım/hayvancilık ülkesi iken Özbekistan'da belirli derecede bir sanayiden söz edilebilir. Kazakistan ve Kırgızistan uluslararası kuruluşların önerileri doğrultusunda hızlı bir şekilde kurumları dönüştürmeye yönelik şok terapi yöntemiyle geçiş stratejisi izlemişken, diğer bazıları "kademeli geçiş" stratejisi izlemiştir. Dolayısıyla bu ülkeleri ortak bir kategoride toplamak da her durumda doğru bir yaklaşım olmayabilir (Çevik ve Turan 2007, Çevik 2010). 
Devletin rolünde gerek geçiş ekonomilerinde gerekse diğer ülkelerdeki bu dönüşüm çoğunlukla üstten aşağı doğru bir yaklaşımla gerçekleştirilmeye çalışılmıştır. Konuya dair akademik çalışmalar da çoğunlukla devletin mali faaliyetlerinin, boyutunun ya da işlevlerinin ekonomik performans üzerindeki etkisi üzerine yoğunlaşmıştır. Dolayısıyla devlet faaliyetlerine dair vatandaş tercihlerinden oluşan talep yanı görece ihmal edilmiştir. Fiili olarak devlet ve piyasanın görece rol bölüşümünün vatandaşların tercih ve tutumlarından etkilenmesi beklenebileceği gibi, vatandaş tercih ve tutumları da fiili durumdan etkilenebiliyor olabilir (Çevik 2018). Bu talep tarafı siyasal sitem aracılığıyla arz tarafını da etkileyebilirken küreselleşme, demografik değişim, devleti küçülmeye yönelik neoliberal reformlar, kamu maliyesi krizleri ve tüm bunların yarattığı sosyal riskler devlete olan talepleri şekillendirebilir (Pitlik ve Kouba 2013: 2). İşte bu çalışmanın temel amacı Orta Asya ülkeleri ve Türkiye örneğinde vatandaşların devlet-piyasa karşıtllğında devletin rolüne ilişkin tercih ve taleplerin belirleyicilerini incelemek ve ülke grupları arasındaki farklıkları belirlemektir. Çalışma vatandaş perspektifinden devletin rolü ve vatandaşların refah devleti talebi ile ilgili görece sınırlı literatüre katkı sağlamayı hedeflemektedir.

Vatandaşların devletin rolüne ilişkin tercihlerini biçimlendiren faktörlere dair iktisadın geleneksel açıklaması, bireylerin kendi çıkarları ilgilenecekleri ve devletin rolüne dair talep ve tercihlerinin de kişisel çıkarları tarafından belirleneceği yönündedir. Ancak kişisel çıkar argümanındaki yetersizlikler, literatürü kişisel çıkar ötesinde demografik faktörlerin, sosyal normların, ahlaki değerlerin, kültürün, siyasal tutumların vb. etkisini incelemeye doğru genişletmiştir.

Kişisel çıkar dışındaki faktörlere odaklanan çalışmalardan bazıları özellikle inanç, ahlaki değer ve siyasal tutumların refah devletine ve yeniden dağıllma dair tercihleri açıklamada daha önemli olduğuna ilişkin bulgular ortaya koymaktadır. Bu yöndeki çalışmalardan biri olmak üzere Fong (2001) kişisel çıkarın yeniden dağılım tercihlerini açıklamakta yetersiz olduğunu bireylerin dağıtıcı adalete dair inançlarının, yoksulluğun nedenine (kişinin kontrolü dışına faktörlerden ya da kişinin kendisinden kaynaklanıp kaynaklanmadığı) dair inançların yeniden dağılım tercihlerini açıklamakta önemli olduğunu göstermektedir. Feldman ve Steenbergen (2001) ise ABD örneğinde hümanist tutum ve değerlerin refah devleti politikalarını desteğini açıklamakta önemli olduğunu ileri sürmektedir. 
Çok sayıda çalışma ülkeler arasındaki kurumsal yapıda, kültürde, siyasal rejim ve kurumlardaki farklılıkların ve siyasal kurumların kalitesinin önemli olduğuna işaret etmektedir. Corneo ve Grüner (2002) Uluslararası Sosyal Anket Programı (ISSP) verisi ile gelir eşitsizliklerini azaltmaya ilişkin bireysel desteği açıklamakta eski sosyalist ülkelerdeki vatandaşlar ile Batı Avrupa ülkelerindeki vatandaşlar arasında sistematik farklılıklar olduğunu ortaya koymuştur. Blekesaune ve Quadagno (2003) yine ISSP verisi ile ulusal düzeyde ideolojik faktörlerin, birey-devlet ilişkisine dair kurumların önemli olduğunu bulmuşlardır. Dallinger (2010) yeniden dağılma ve eşitsizliğe karşı tutumları açıklamakta politik değişkenlerin, kurumların ve kültürün önemli olduğunu göstermiştir. Svallfors (2012) Avrupa Sosyal Araştırması (ESS) verisi üzerinden kamu kurumlarının kalitesine dair algının vergi ve harcamalara dair tutumlar üzerinde açık bir etkiye sahip olduğunu, daha kaliteli ve etkin kurum algısının daha yüksek vergi ve harcama tutumu ile ilişkili olduğunu göstermiştir. Roosma et al. (2013) yine aynı veriye dayanarak Doğu ve Güney Avrupa ülkelerinde bireylerin devletin ve politikaların etkinliğine ilişkin eleştirel görüşleri ile devletin rolüne ilişkin pozitif tutumları arasında bir birliktelik olduğunu ortaya koymuştur. Jakobsen (2011) refah devletine ilişkin tutumlarla refah rejimi tipolojileri ve sosyal harcamalar arasındaki ilişkiyi araşıırmıs ve liberal ve muhafazakâr rejimlere sahip ülkeler arasında refah devletine ilişkin tutumlarda istatistiksel olarak anlamlı fark bulunmuştur. Liberal rejimli ülkelerdeki vatandaşlar refah devleti ile ilgili daha sağcı tutuma sahiptir.

Bazı çalışmalar bireyle toplum arasındaki etkileşimin ürünü olarak sosyal normların, kültürün, bireylerin ahlaki ve politik tutum/değerlerinin etkisine odaklanmaktadır. Alesina ve Giuliano (2009) ABD Genel Sosyal Anketi ve Dünya Değerler Araştırması (WVS) verisi ile yeniden dağılıma ilişkin tercihlerin belirleyicilerini araştırmıştır. Bulgularına göre yeniden dağı lım tercihleri $\mathrm{ABD}$ için yaş, cinsiyet, rrk ve sosyo-ekonomik statü gibi bireysel karakteristiklerin yanı sıra tarih, kültür, siyasal ideoloji ve adalet algısının bir ürünü olarak ortaya çıkmaktadır. Aynı zamanda ülkeler arasında yeniden dağılım tercihleri arasında büyük farklılıklar bulunduğunu ve bu farklılıkların din, makroekonomik dalgalanmalar ve kültürle ilişkili olduğunu ortaya koymuşlardır. Stegmüller et al. (2011) yeniden dağılıma ilişkin tercihler 
üzerinde dinin önemli bir açıklayıcı değişken olduğunu bulmuştur. Çalışmanın bulgularına göre dindar bireyler yeniden dağıııcı politikalara karşı bir tutuma sahipken dindar ve seküler bireyler arasında kutuplaşmanın yüksek olduğu yerlerde yeniden dağılıma olan destek daha düşük gözükmektedir. düşük olduğuna dair ampirik bulgu elde etmişlerdir. Pitlik ve Kouba (2013) tarafından elde edilen bulgulara göre sosyal güven ve hayat kontrol algısı yeniden dağılıma ve devlet müdahalesine olan bireyse desteği artırmakta, dindarlık yeniden dağılıma ve devlet müdahalesine daha az destekle birliktelik göstermektedir. Bergh ve Bjørnskov (2013) güvenin eşitsizliği azaltabilecek refah devleti politikalarını desteklediği ancak eşitsizlikte azalmanın güveni artırmadığını ortaya koymuştur. Bjørnskov (2007) ise gelir eşitsizliğinin sosyal güveni azalttığını ortaya koymuştur.

Bir kısım çalışma ise makroekonomik yapı ve değişkenlerle devletin rolüne ilişkin tutumlar arasında ilişkiyi araştırmıştır. Jaeger (2013) ESS verisine dayanarak, makroekonomik ve sosyal koşullarda ülkeler arasındaki farklılıkların yenden dağılım talebini açıklamakta önemli olduğunu, düşük ekonomik büyümenin ve yüksek gelir eşitsizliğinin daha düşük yeniden dağılım talebi yarattığını bulmuştur. Koster (2009) refah devletine dair tutumlar ile AB ülkelerinin ekonomik bütünleşmesi arasındaki ilişkiyi araştırmış ve bu iki değişken arasında ters-U biçimli bir ilişki olduğunu bulmuştur.

Bu çalışmaların bulgularından da yararlanarak, bu çalışmada devletin rolüne dair vatandaş tercihlerinde ülke grupları arasındaki farklılıkların incelenmesi ve devlet-piyasa karşıtlığının en belirgin olduğu boyut olarak gelir eşitsizliğine dair tutumlarda (yeniden dağılım) ve kamu-özel mülkiyete ilişkin tercihlerde bireyler arasındaki farklılıkların belirleyicilerini Orta Asya Ülkeleri ve Türkiye verileri ile incelenmesi amaçlanmaktadır.

Çalışmada önce ülke grupları arasındaki farklılıklar zaman boyutunda değişimle ve Türkiye ve Orta Asya ülkelerinin pozisyonunu gösterecek biçimde incelenmektedir. Arkasından Türkiye, Azerbaycan, Kazakistan, Kırgızistan ve Özbekistan için ayrı ayrı olmak üzere OLS regresyonları ile demografik, sosyo-ekonomik, sosyal sermaye ve siyasal eğilim ve değerlere dair açılkayıc1 değişkenlerle analiz edilmektedir. Böylece hem bu değişkenlerin yeniden dağılıma ve kamu mülkiyetine dair tutumları açılama gücünü hem de Orta Asya ve Türkiye (OAT) kapsamındaki ülkeler arasında açılayıcı güçlerinde bir farklılık olup olmadığı değerlendirilmektedir. 


\section{Veri ve Yöntem}

Refah devletine ilişkin tutumlar arasındaki farklılıklar, bireysel farklılıklar tarafından belirlenen bireysel bir fenomen olduğu kadar, ülkelerin ekonomik, demografik, devletin refah rejiminin bir yansıması olarak kamu maliyesi, sosyal ve politik kurumsal yapılarının da bir sonucu olarak ülke düzeyinde ele alınması gereken kolektif bir fenomen olarak düşünülebilir (Blekesaune and Quadagno 2003: 415). Bu nedenle çalışmada refah devleti ve bireylerin devletin ekonomideki rolüne ilişkin tutumlarını her iki boyutu ile incelenmektedir. Önce ülke gruplarına göre refah devletine ilişkin tutumlardaki farklılıklar Türkiye’nin ve Orta Asya ülkelerinin pozisyonlarını gösterecek şekilde karşılaştırılmakta daha sonra Orta Asya ülkeleri ve Türkiye için regresyonlar ile refah devletine ilişkin tercih ve tutumların bireysel düzeyde belirleyicilerini analiz edeceğiz.

Çalışmada kullanılan veriler WVS (2016) ve EVS (2016) kapsamında toplanmış verisetlerinin birleştirilmesinden elde edilmiştir. Birleştirme, örneklemi genişletmek amacıyla yapılmıştır. Birleştirilmiş verisetinin kapsamı ve orijinal verisetleri ilişkisi Tablo-1'de sunulmaktadır.

Tablo 1. WVS-EVS Dalgalarl

\begin{tabular}{|c|c|c|c|c|}
\hline $\begin{array}{l}\text { Birleştirilmiş } \\
\text { Dalga Kodu }\end{array}$ & $\begin{array}{l}\text { Birleştirilmiş Dalga- } \\
\text { ların Kapsadığı Yıllar }\end{array}$ & $\begin{array}{c}\text { Orijinal } \\
\text { EVS Dalgası } \\
\end{array}$ & $\begin{array}{c}\text { Orijinal WVS } \\
\text { Dalgası } \\
\end{array}$ & $\begin{array}{c}\text { Türkiye } \\
\text { Anket Yılı }\end{array}$ \\
\hline 1. Dalga & $1981-1984$ & $\begin{array}{c}\text { EVS 1 } \\
(1981-1994)\end{array}$ & $\begin{array}{c}\text { WVS 1 } \\
(1981-1984)\end{array}$ & 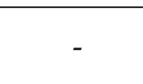 \\
\hline 2. Dalga & $1989-1993$ & $\begin{array}{c}\text { EVS 2 } \\
(1990-1993)\end{array}$ & $\begin{array}{c}\text { WVS } 2 \\
(1989-1993)\end{array}$ & 1990 \\
\hline 3. Dalga & 1994-1998 & - & $\begin{array}{c}\text { WVS } 3 \\
(1994-1998)\end{array}$ & 1996 \\
\hline 4. Dalga & 1999-2004 & $\begin{array}{c}\text { EVS 3 } \\
(1999-2001)\end{array}$ & $\begin{array}{c}\text { WVS } 4 \\
(1999-2004)\end{array}$ & 2001 \\
\hline 5. Dalga & 2005-2009 & - & $\begin{array}{c}\text { WVS } 5 \\
(2005-2009)\end{array}$ & 2007 \\
\hline 6. Dalga & $2008-2010$ & $\begin{array}{c}\text { EVS } 4 \\
(2008-2010)\end{array}$ & - & 2009 \\
\hline 7. Dalga & $2010-2014$ & - & $\begin{array}{c}\text { WVS } 6 \\
(2010-2014)\end{array}$ & 2011 \\
\hline
\end{tabular}

Her iki araştırmada bireylerin devletin ve piyasanın görece rolüne ilişkin tercihlerini belirlemeye ve katılımcıların iktisadi yelpazede kolektivist - bireyci olarak sıralamaya yardımcı olacak bir dizi soru bataryası içermektedir. 
Tablo-2 bu çalışmada karşılaştırmalarda ve analizlerde devlete ve piyasaya dair tutumları yönelik tutumları ölçmekte kullanılan ifadeleri göstermektedir. Çalışmanın 3. Bölümünde tüm bu değişkenlere verilen bireysel cevapların ülke ortalamaları üzerinden ülke grupları arasında karşılaştırma sunulmaktadır. Çalışmanın 4. Bölümünde ise bu değişkenlerden devlet-piyasa ilişkisini doğrudan yansıttığı varsayılabilecek yeniden dăğlım ve mülkiyetin belirleyicilerini bireysel düzeyde regresyonlar aracilığıyla Orta Asya Ülkeleri ve Türkiye örneklemleri ile incelenmektedir.

Tablo 2. Devlet ve Piyasaya İlişkin Tutumları Gösterir Değişkenler

\begin{tabular}{|c|c|c|c|}
\hline Değişken & 1. basamaktaki ifade & 10. basamaktaki ifade & WVS-EVS Kodu \\
\hline $\begin{array}{l}\text { Yeniden Dağılım } \\
\text { Tercihi } \\
\text { (yeniden dağılım) }\end{array}$ & $\begin{array}{l}\text { Kişisel çabaları teşvik } \\
\text { için gelirlerin daha } \\
\text { farklı olması gerekir }\end{array}$ & $\begin{array}{l}\text { Gelirler daha eşit hale } \\
\text { getirilmelidir. }\end{array}$ & $\begin{array}{l}\text { E035 (cevaplar } \\
\text { orijinaline göre } \\
\text { ters kodland1. ) }\end{array}$ \\
\hline $\begin{array}{l}\text { Kamu-Özel } \\
\text { Mülkiyet } \\
\text { (mülkiyet) }\end{array}$ & $\begin{array}{l}\text { İşyerlerinin ve } \\
\text { sanayi kuruluşlarının } \\
\text { mülkiyeti daha fazla } \\
\text { özel olmalıdır. }\end{array}$ & $\begin{array}{l}\text { İşyerlerinin ve } \\
\text { sanayi kuruluşlarının } \\
\text { mülkiyeti daha fazla } \\
\text { devletin olmalıdır. }\end{array}$ & E036 \\
\hline $\begin{array}{l}\text { Devlet - Birey } \\
\text { Sorumluluğu } \\
\text { (sorumluluk) }\end{array}$ & $\begin{array}{l}\text { Devlet, tüm yurttaşla- } \\
\text { rın geçimlerini temin } \\
\text { hususunda daha fazla } \\
\text { sorumluluk almalıdır. }\end{array}$ & $\begin{array}{l}\text { Kişiler kendi geçimle- } \\
\text { rinden kendileri daha } \\
\text { fazla sorumlu olmalıdır. }\end{array}$ & E037 \\
\hline $\begin{array}{l}\text { Rekabete Karş1 } \\
\text { Tutum } \\
\text { (rekabet) }\end{array}$ & $\begin{array}{l}\text { Rekabet iyi bir şeydir. } \\
\text { İnsanların daha çok } \\
\text { çalışmasını ve yeni } \\
\text { fikirler üretmesini } \\
\text { sağlar. }\end{array}$ & $\begin{array}{l}\text { Rekabet zararlıdır. } \\
\text { İnsanların içindeki } \\
\text { kötü duyguları ortaya } \\
\text { çıarır. }\end{array}$ & E039 \\
\hline $\begin{array}{l}\text { Çalışma-Başarı } \\
\text { İlişkisi (çalışma) }\end{array}$ & $\begin{array}{l}\text { Çok çalışan er ya da } \\
\text { geç iyi bir yaşantıya } \\
\text { kavuşur. }\end{array}$ & $\begin{array}{l}\text { Başarı çalışmaktan çok } \\
\text { şansa, torpile, tanıdığa } \\
\text { bağlıdır. }\end{array}$ & E040 \\
\hline $\begin{array}{l}\text { Servet Birikimine } \\
\text { İlişkin Tutum } \\
\text { (servet) }\end{array}$ & $\begin{array}{l}\text { Birinin zenginliği } \\
\text { diğerinin fakirliği } \\
\text { demektir. }\end{array}$ & $\begin{array}{l}\text { Bu dünyada herkese } \\
\text { yetecek kadar servet } \\
\text { vardır. }\end{array}$ & E041 \\
\hline
\end{tabular}

Her iki anketin ilk dalgasında, devletin/piyasanın rolüne ilişkin tutumlarına dair sorular bulunmadığından, ülkeler arasında yapılan karşılaştırmalarda ikinci dalgadan itibaren veriler değerlendirilebilmiştir. Ancak bu durumda dahi 1980'lerin sonu, 1990'ların başı ile 2010'ların başı arasında yaklaşık 20 yıllık bir dönemi değerlendirmek ve zamana karşı bir karşılaştırma yapmak mümkün olmaktadır. 
Veri ile ilgili bir diğer kısıtlama Orta Asya ülkeleri için anketlerin farklı dalgalarda ölçümü sınırlı olduğundan zaman boyutunda bu ülkelerde bir karşılaştırma yapmak mümkün olmamaktadır. Azerbaycan (1997, 2008 ve 2011) ve Kırgızistan (2003 ve 2011) için farklı yıllarda anket uygulanmıssa da Kazakistan ve Özbekistan sadece WVS'nin 6. Dalgası kapsamında 2011 yılında veri toplanmıştır. Bu yüzden ülke karşılaştırmaları bu ülkeler 2011 yılı verileri diğer ülke gruplarının aynı dalga kapsamında toplanan verileri ile karşılaştırılarak yapılmıştır. Regresyonlarda ise veri olan tüm yıllar analizlere eklenmiş ancak birden fazla dalgada ölçüm olan ülkelerde kukla değişkenle yıllar arasındaki farklılık kontrol altına alınmıştır.

\section{Devlete Piyasaya İlişkin Tutumlarda Ülkeler Arası Karşılaştırma}

Genel olarak devletin ve piyasanın rolüne ilişkin bireysel tutum ve tercihlerin bireysel faktörlerin yanı sıra ülkenin ekonomik, politik ve sosyal kurumlarının etkisi ile şekillendiği kabul edilebilir. Bu nedenle ülkeler ve ülke grupları arasında farklılıklar beklenebilir. Öte yandan zamana bağlı olarak bu tür tercihlerin nasıl değisstiği de önemli bir ilgi konusudur.

Bu iki hususu değerlendirmek üzere bu bölümde, zamana bağlı olarak ekonomik ve politik olarak ortak bazı özelliklere sahip çeşitli ülke gruplarında ortalama olarak devletin/piyasanın rolüne ilişkin tercihlerin nasıl değiştiğini karşılaştırmalı olarak incelenmektedir. Mümkün olan yerlerde Orta Asya ülkeleri ve Türkiye, WVS 6. Dalga verileri ile diğer ülke grupları ile karş1laştırılmaktadır.

\section{Yeniden dağılım tercihleri}

Şekil-1 bazı ülke grupları ve Türkiyede yeniden dağılıma ilişkin tutumları ülke ortalaması ile karşılaştırmaktadır. Karşılaştırmalarda gelişmekte olan yükselen ekonomileri (BRIICST) ${ }^{1}$, 1990'ların başında sosyalist blokun çöküşüyle kumanda ekonomisinden serbest piyasa ekonomisine geçiş yapan ve çoğu Doğu Avrupa, Balkan ve Orta Asya ülkelerinden oluşan geçiş ekonomilerini $^{2}$ ve geçiş ülkeleri haricinde kalan ve çoğunlukla yüksek gelir grubu olarak tanımlanabilecek $\mathrm{AB}$ ülkeleri değerlendirilmiştir.

Daha yüksek değerler, daha yüksek yeniden dağıtım yanlısı tutumu yansıttığı dikkate alınırsa Şekil-1'de görüldügü gibi Türkiye hariç tüm ülke grup- 
larında 1980'lerin sonu ile 2010'ların başı arasındaki yaklaşık 20 yılı aşkın bir zaman diliminde yeniden dağılıma ilişkin vatandaş taleplerinin arttığı gözlemlenebilir. Bu artış küreselleşme ve uluslararası organizasyonlar desteği ile yürütülen devleti küçültücü ve devlet müdahalesini azaltıcı reformlara olan tepkiler ve bu tür reformların bölüşümsel sonuçları ile ilgili görülebilir. Öte yandan özellikle 2008 finansal krizi sırası ve sonrasını gösteren son üç dalgada bu artışın istikrarlı olduğu da görülmektedir.

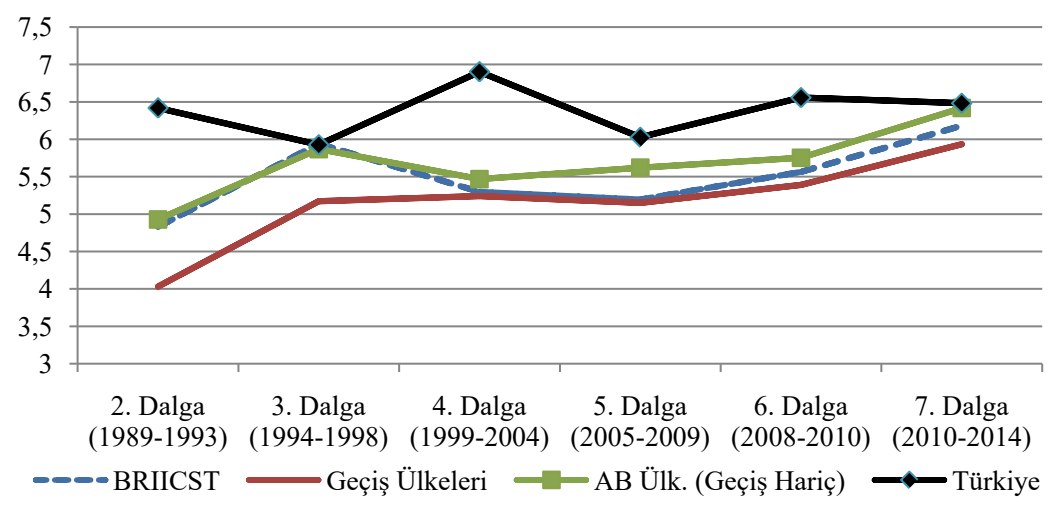

Şekil 1. Ülke Gruplarına Göre Yeniden Dağ̊lım Tercihi

Şekilde izlenebilecek bir diğer eğilim dönemler arasında en yüksek artış geçiş ekonomilerinde izlenmektedir. Geçiş ekonomilerinde ortalama yeniden dağ 1 lım talebi 4 düzeylerinden 2 puan artışla 6 puan düzeylerine gelmiştir. Son olarak Türkiye'de yeniden dağılım talebinin ülke grupları ortalamalarından yüksek olduğu ancak yıllar arasındaki dalgalanmalara rağmen 1990 ile 2011 arasında görece değişmediği görülmektedir. Türkiye'deki dalgalanmalar ekonomik krizlerin ve buna bağlı olarak kişi başı gelirdeki dalgalanmalar ve gelir dağılımında bozulmaların yeniden dağılıma ilişkin taleplerde etkili olabileceği izlenimini vermektedir. Türkiye'de 3. Dalga kapsamındaki ölçüm 1994 krizinden çıkıldıktan 1996 yılında, 4. Dalga kapsamındaki ölçüm oldukça büyük bir kriz dönemi olan 2001 yılında, 5. Dalga kapsamındaki ölçüm ekonominin oldukça istikrarlı kabul edildiği 2007 yılında ve 6. Dalga kapsamındaki ölçüm Dünya Finansal Krizinin Türkiye üzerindeki etkilerinin hissedildiği 2009 yılında elde edilmiştir. Bu bağlamda kriz dönemlerinde (özellikle 2001 ve 2009 için) 
işsizlikte artışlar, gelirde azalmalar ve gelir dağılımında bozulmalar sonucu daha yüksek bir ortalama yeniden dağılım talebi oluştuğu düşünülebilir.

Şekil-1'in düşündürdüğü bir diğer husus gelir ve refah düzeyinin yeniden dağılım talebi üzerinde etkili olabileceğidir. Şekil-2 ülkelerin kişibaşı gelir düzeyleri ile ortalama yeniden dağılım talebi arasındaki ilişkiyi saçılım grafikleri ve basit regresyon bulguları ile sunmaktadır. (A) Panelinden görülebileceği gibi kişibaşı gelir düzeyi ile yeniden dağılım talebi arasında ülke düzeyinde pozitif bir ilişki bulunmaktadır $(\mathrm{R} 2=0.10)$. Buna göre daha yüksek gelir seviyesindeki ülkelerde daha yüksek eşitlik talebi bulunmaktadır. Yüksek gelirli çoğu ülkenin görece daha 1 lımlı gelir eşitsizliği problemine sahip olduğu (dolayısıyla gelir seviyesi görece düşük) ve gelişmekte olan ülkelerde gelir dağılımı sorunlarının daha ağır olacağı dikkate alınırsa, bu bulgu ülkelerin ekonomik öncelikleri ile ilgili olarak da değerlendirilebilir. Çoğu gelişmekte olan ülke ekonomik öncelik olarak ekonomik büyümeye odaklanmış durumdadır ve bu belirli ölçüde sosyal tercihlere de yansımıştır.

(A)

Yeniden Dağılım Tercihi ve Gelir Düzeyi

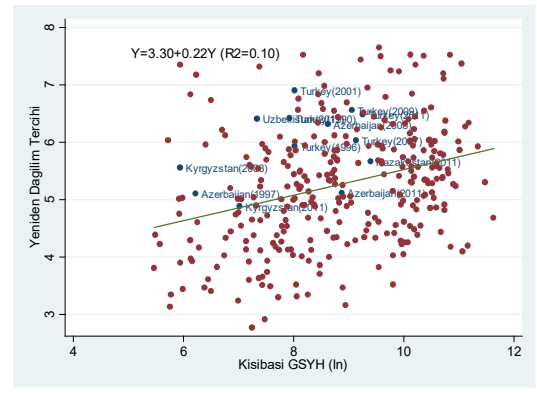

(B)

Yeniden Dağılım Tercihinde Homojenlik ve Gelir Düzeyi

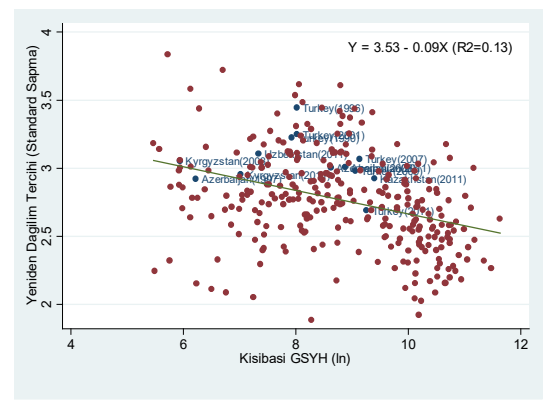

Şekil 2. Yeniden Dağılım Tercihi ve Gelir Düzeyi

Şekil 2’nin (B) Paneli yeniden dağılım talebinin ülke düzeyinde ne derece homojen olduğunu değerlendirmek üzere, bu soruya erilen cevapların standart sapması ile ülkenin kişibaşı gelir düzeyi arasındaki ilişkiyi sunmaktadır. Buna göre gelir düzeyi yükselirken ülke içinde gelir eşitsizliğine ilişkin tutumdaki farklılıkların da azaldığı söylenebilir. Yüksek gelir düzeyinde vatandaşlar gelir eşitsizliğine ilişkin daha fazla uzlaşmalı görüş ileri sürmektedirler. 

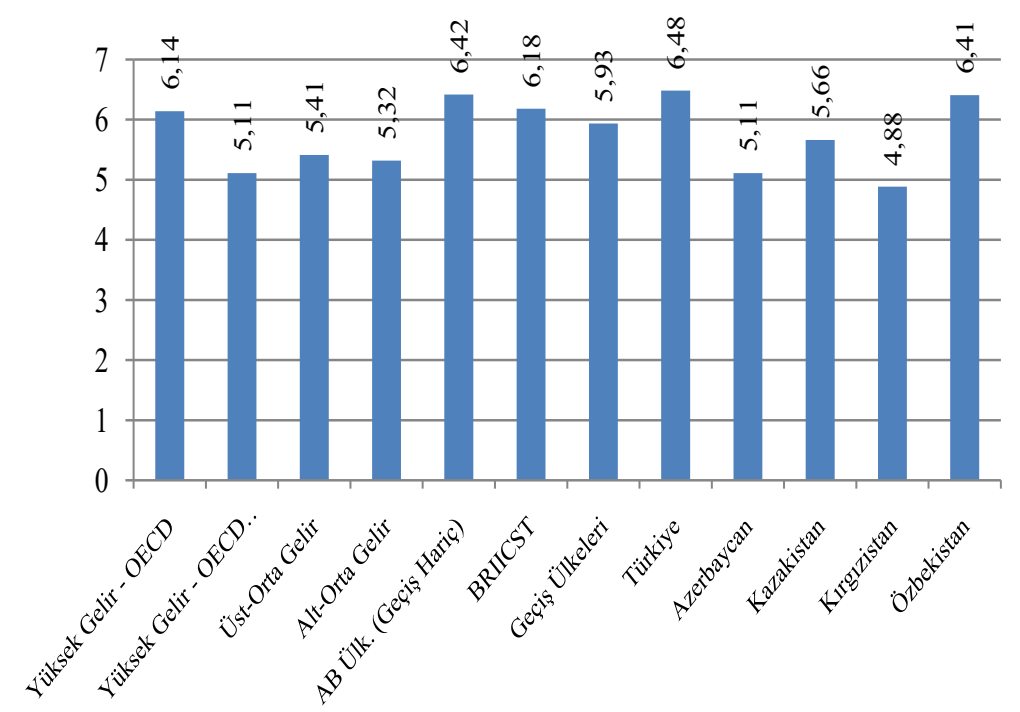

Şekil 3. Orta Asya ve Türkiye'de Yeniden Dăğlım Talebi

Şekil-3 ise WVS 6. Dalga kapsamında toplanan verilerle Orta Asya Ülkeleri ve Türkiye'yi (OAT) diğer bazı ülke grupları ile karşılaştırmaktadır. OAT ülkeleri arasında en yüksek yeniden dağılım talebi Türkiye ve arkasından Özbekistan'dadır. Bu iki ülkedeki ortalama Yüksek Gelirli OECD ülkeleri ve $A B$ ülkeleri ile hemen hemen aynı düzeydedir. Öte yandan özellikle Azerbaycan ve Kırgızistan geçiş ekonomileri ortalamasının da altında bir yeniden dağılım tercihi sergilemektedir.

\section{Kamu/Özel müllkiyete ilişkin tutumlar}

Devlet ve piyasa arasında fonksiyon bölüşümünün bir diğer boyutu, ticari faaliyet ve işletmelerin mülkiyetinin devlete mi özel sektöre mi ait olacağıdır. 1980 'lerden itibaren tüm dünyada başlayan özelleştirme/serbestleştirme çabaları kamu mülkiyetindeki ekonomik faaliyetlerin özel sektöre devrini gerçekleştirerek kaynak kullanımına ilişkin kararların özel sektörde alınmasını hedeflemiştir. 1990'lardan itibaren geçiş ekonomilerinde piyasa sistemin geçişe yönelik reformların en somut boyutu da yine kamu mülkiyetinin özel kesime devri olmuştur. 


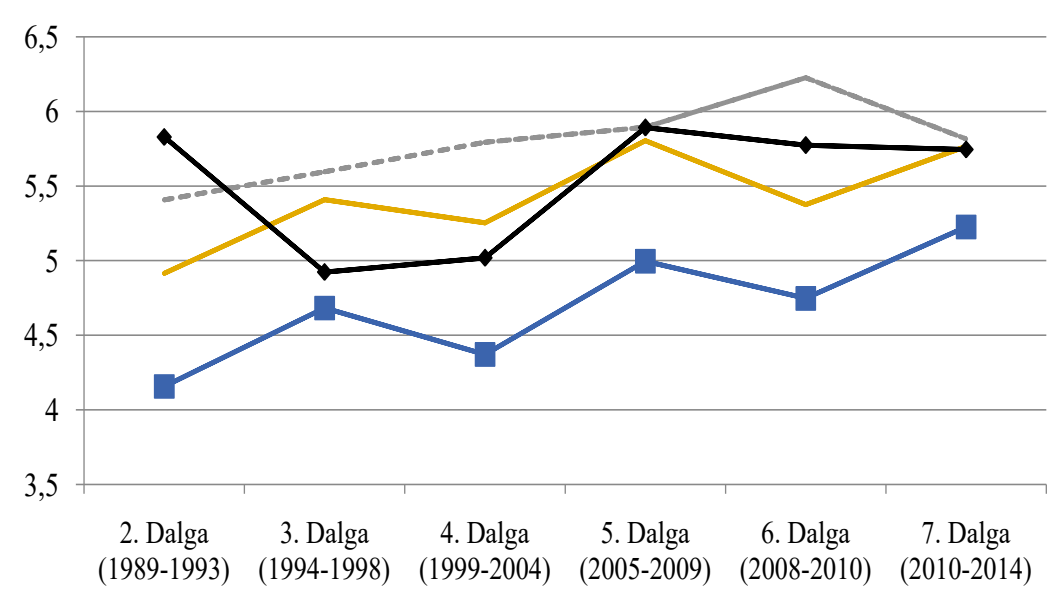

Şekil 4. Ülke Gruplarnna Göre Kamu/Özel Mülkiyet Tercibi

Şekil 4 mülkiyet tercihin ilişkin ülke ortalamalarını karşılaştırmaktadır. Görüleceği gibi ülke gruplarının çoğunda sözkonusu dönem boyunca devlet mülkiyeti yönünde tercihler artmıştır. Şekilde izlenecek eğilimlerden biri 2008 krizi sonrasında özel sektöre olan güven azalması ile çoğu ülkede devlet mülkiyetine olan talebin artmış olmasıdır. İkinci bir önemli eğilim yüksek gelirli ülkelerden oluşan $\mathrm{AB}$ ülkeleri diğer ülke gruplarından oldukça düşük ortalamaya sahipken gelişmekte olan ülkelerde ve geçiş ekonomilerinde daha yüksek kamu mülkiyeti talebi bulunmaktadır. Bu da kalkınma seviyesinin bu yöndeki vatandaş taleplerinde önemli olacağını göstermektedir.

Kişibaşı gelir seviyesi ile mülkiyet talebi arasındaki ilişkiyi sunan Şekil-5 incelendiğinde de gerçekten kalkınma düzeyi ile devlet mülkiyetine olan talep arasında negatif yönlü bir ilişki olduğunu göstermektedir. Ülkelerin gelir seviyesi yükselirken şirket ve firmaların devlet mülkiyetine olan talebi azalmaktadır. 
(A)

Kamu/Özel Mülkiyete İlişkin Tutumlar ve Gelir Düzeyi

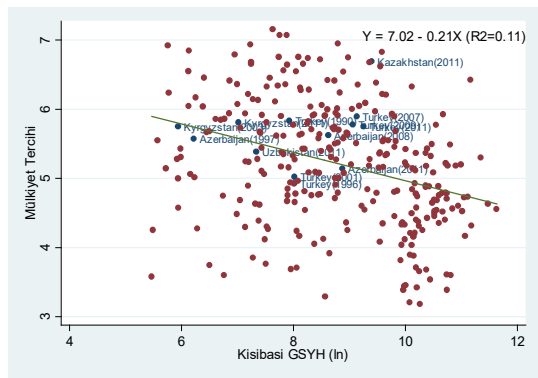

(B)

Mülkiyet Tercihinde Homojenlik ve Gelir Düzeyi

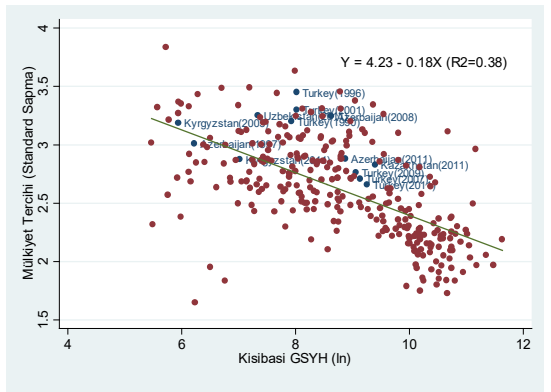

Şekil 5. Kamusal/Özel Mülkiyet Tercihi ve Gelir Düzeyi

Şekil 5'in (B) Paneli ise bu tercihlerdeki homojenlikle ülkelerin gelir seviyesi arasındaki ilişkiyi göstermektedir. Görüleceği gibi oldukça kuvvetli bir biçimde $\left(\mathrm{R}^{2}=0.38\right)$ gelir yükselirken mülkiyete ilişkin taleplerde vatandaşlar arasında homojenlik artmaktadır.
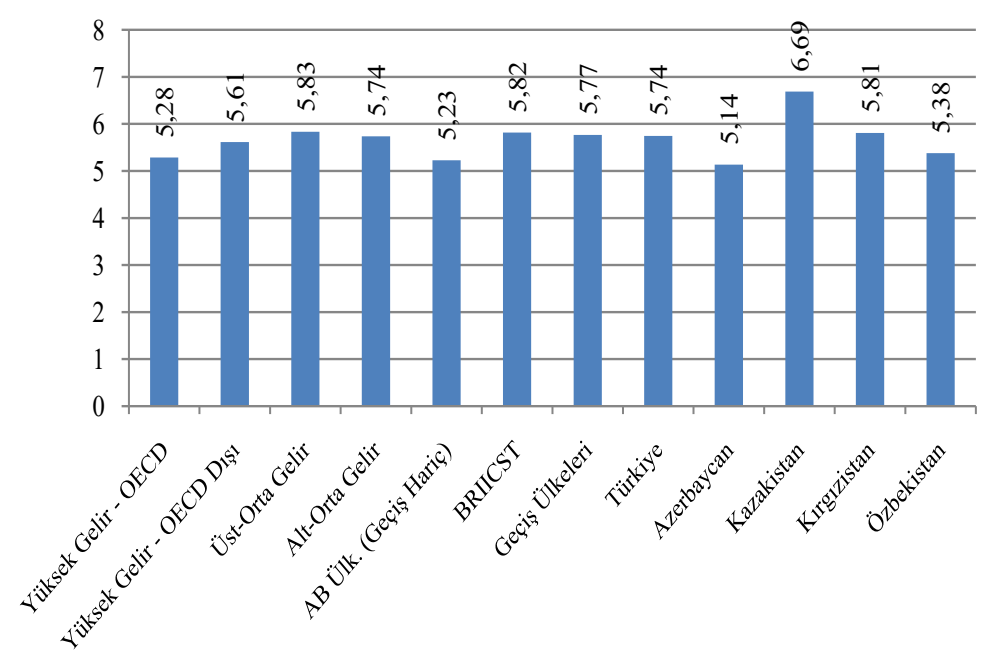

Şekil 6. Orta Asya Ülkeleri ve Türkiye'de Mülkiyet Tercihleri

Şekil 6 OAT'de devlet mülkiyetin ilişkin tercihleri ortalama olarak karşılaştırmaktadır. Görüleceği gibi yüksek gelirli $\mathrm{OECD}$ ülkeleri ve $\mathrm{AB}$ ülkeleri 
görece düşük kamu mülkiyeti tercihi sergilemektedir. Kazakistan karşılaştırılan tüm ülke ve ülke grupları arasında en yüksek kamu mülkiyeti tercihine sahip ülkedir. OAT arasında en düşük devlet mülkiyeti taraftarı ülke Azerbaycan'dır. Türkiye, Kırgızistan ve Özbekistan diğer geçiş ekonomilerine ve gelişmekte olan ülkelere benzer eğilim sergilemektedir.

\section{Devlet sorumluluğu-bireysel sorumluluğa ilişkin tutumlar}

Değerlendireceğimiz bir diğer husus vatandaşların geçimlerini temin etmek hususunda devlete ne derece sorumluluk atfettikleridir. Bu özellikle refah devleti faaliyetlerine, devlet tarafından sağlanan sosyal güvenlik ve sosyal yardımlara vatandaşların tutumunu göstermek açısından önemlidir. Sosyal yardımlar ve sosyal güvenlik 20. yüzyıl boyunca devlet faaliyetlerinde genişlemenin ve refah devletinin büyümesinin en önemli nedenlerinden biri olmuştur. Ekonomide devletin rolüne tutumlarda vatandaşlar arasında popüler görüş farklılıklarının önemli bir bölümü de devletin sosyal yardım, refah hizmetleri ve sosyal güvenliğe dair rolü ile ilgilidir.

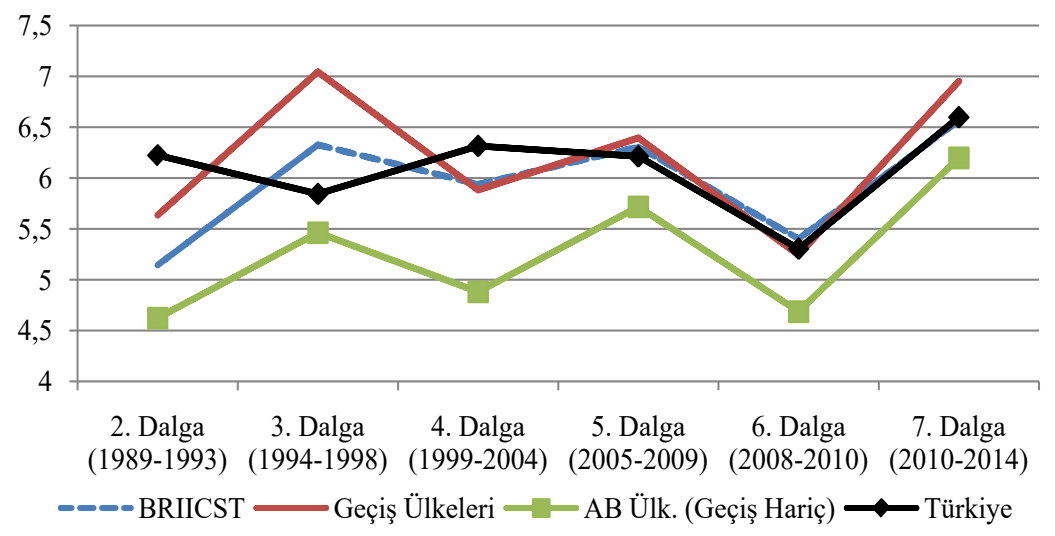

Şekil 7. Ülke Gruplarna Göre Devlet/Bireysel Sorumluluk Tercibleri

Şekil 7 bu tercihleri ülke grupları itibariyle karşılaştırmaktadır. Yine görüleceği gibi yüksek gelirli ülke gruplarında bireysel sorumluluğa daha fazla ağırlık verilmektedir. Bir diğer önemli trend tüm ülke gruplarında son dalgada devlet sorumluluğuna daha fazla ağırlık vermek yönünde bir değişim izlenmiştir. 
(A)

Sorumluluk Tercihi ve Gelir Düzeyi

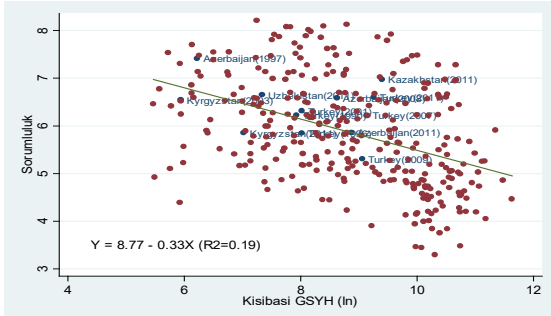

(B)

Sorumluluk Tercihinde Homojenlik ve Gelir Düzeyi

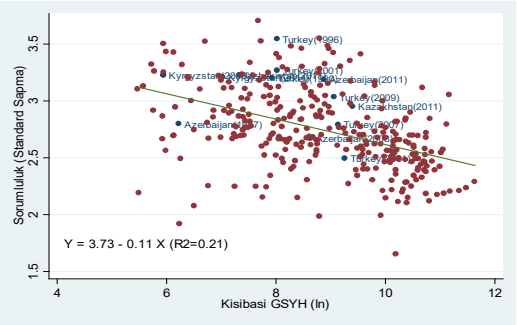

Şekil 8. Devlet/Bireysel Sorumluluk Tercihi ve Gelir Düzeyi

Şekil 8 ise sorumluluğa dair tercihlerin ülkelerin kişibaşı gelir seviyesi ile ilişkisini göstermektedir. (A) Panelinde görüldüğü gibi ülkelerin gelir seviyesi artarken bireysel sorumluluğa daha fazla ağırlık verilmektedir $\left(\mathrm{R}^{2}=0.19\right)$. Öte yandan (B) Paneli, gelir yükselirken sorumluluğa dair tutumlarda ülke içinde uylaşımın arttığını göstermektedir.

Orta Asya ve Türkiye'de devlet/bireysel sorumluluğa ilişkin tutumları diğer ülke grupları ile birlikte karşlaştıran Şekil-9'dan görüldügüu gibi yüksek gelirli ülkelerde $\mathrm{AB}$ ülkelerinde devlet sorumluluğuna ilişkin talepler düşük diğerlerine görece düşüktür. OAT arasında ise Kazakistan mülkiyet tercihinde de olduğu gibi sorumluluğa dair tercihlerde de en yüksek değere sahiptir. Yine Azerbaycan ve Kırgızistan devlet sorumluluğuna, geçiş ekonomileri ortalamasına göre düşük ağırlık vermektedir. Türkiye, Kazakistan ve Özbekistan ortalamaları, geçiş ekonomileri ve gelişmekte olan ülkelerin ortalamaları civarındadır.
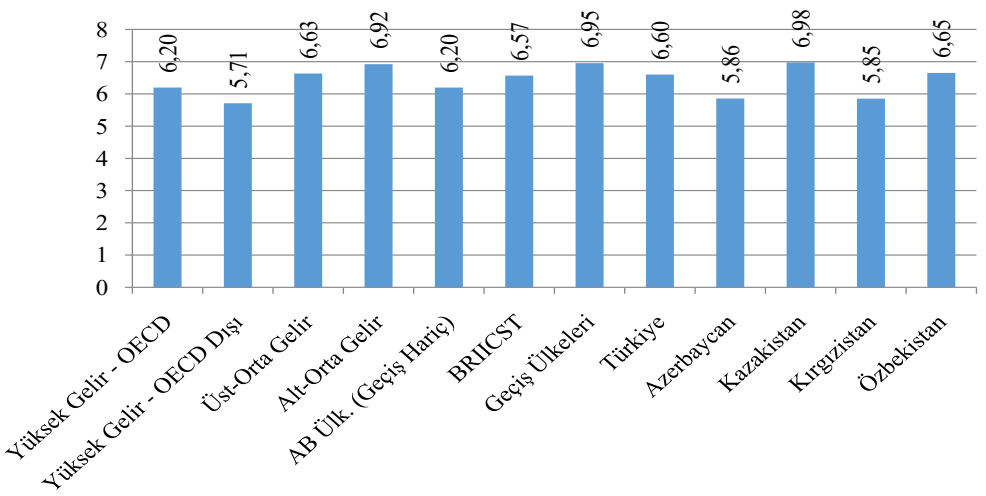

Şekil 9. Orta Asya ve Türkiye'de Sorumluluğa İlişkin Tercihler 


\section{Rekabete dair tutumlar}

Karar alma ve kaynak dağıtım mekanizması olarak devlet ve piyasaya yüklenen fonksiyonlar rekabetin değerine dair kabullerle de yakından ilişkilidir. Bilindiği üzere serbest piyasa ekonominin toplumların ekonomik refahının en iyi mekanizması olduğunu savunanların en önemli kabulü, rekabetin kaynakları daha etkin kullanmak açısından birey ve firmalara motivasyon yaratacağıdır. Öte yandan bazı görüşler kontrol edilmemiş rekabetin ekonomik ve sosyal yapılar açısından yıkıcı sonuçlar doğuracağını düşünür.

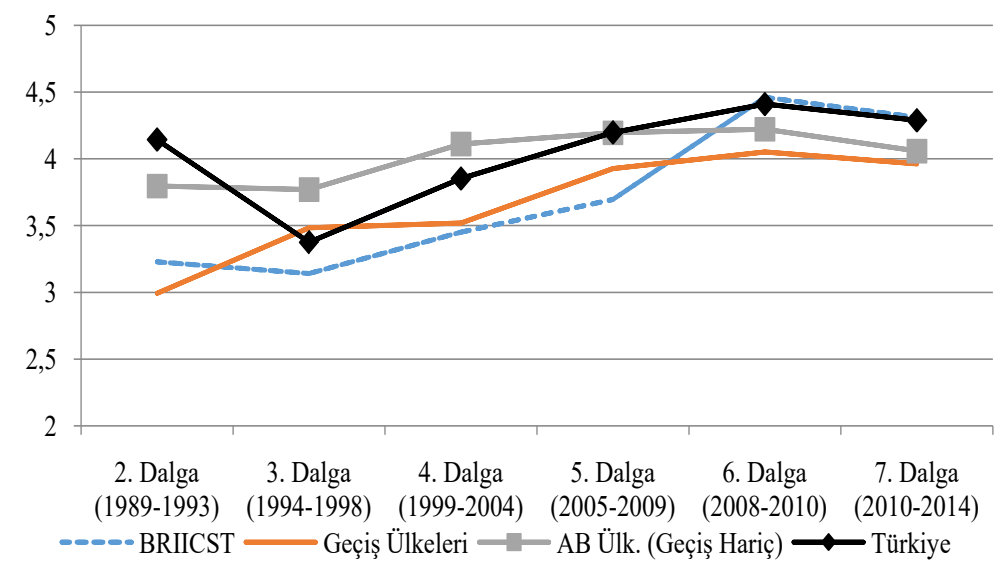

Şekil 10. Ülke Gruplarna Göre Rekabete Karşı Tutumlar

WVS/EVS kapsamında sorulan bir diğer soru, bireylerin rekabetin insanları daha çok çalışmaya ve yeni fikirler bulmaya sevk edeceği için iyi bir şey mi yoksa insanların içindeki kötü duyguları ortaya çıkaracağından kötü bir şe mi olarak değerlendirdiklerini sormaktadır.

Ülke gruplarına göre rekabete ilişkin tutumları karşılaştıran Şekil-10 dönem boyunca rekabetin kötü bir şey olduğuna dair görüşlerin ağırlık kazandığını göstermektedir. Yüksek ortalama rekabete dair daha olumsuz görüşleri göstermektedir. 6. dalgaya kadar AB ülkeleri diğer ülke grupların daha yüksek ortalama sahiptir. 
(A)

Rekabete Karşı Tutumlar ve Gelir Düzeyi

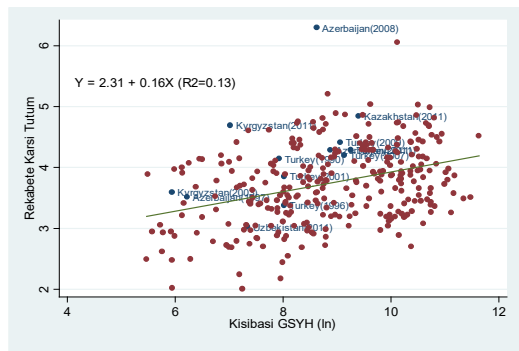

(B)

Rekabete Karşı Tutumlarda Homojenlik ve Gelir Düzeyi

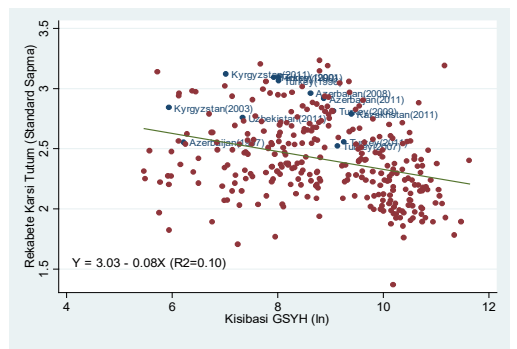

Şekil 11. Rekabete Karşı Tutum ve Gelir Düzeyi

Şekil 11'in (A) Panelinden görüleceği gibi kişibaşı gelir düzeyi yükselirken rekabete dar olumsuz tutumlar artmaktadır $(\mathrm{R} 2=0.13)$. (B) panelinden görüldüğü gibi diğer durumlarda da olduğu gibi gelir seviyesindeki artış vatandaşlar arasındaki görüşlerdeki homojenlik artmaktadır.

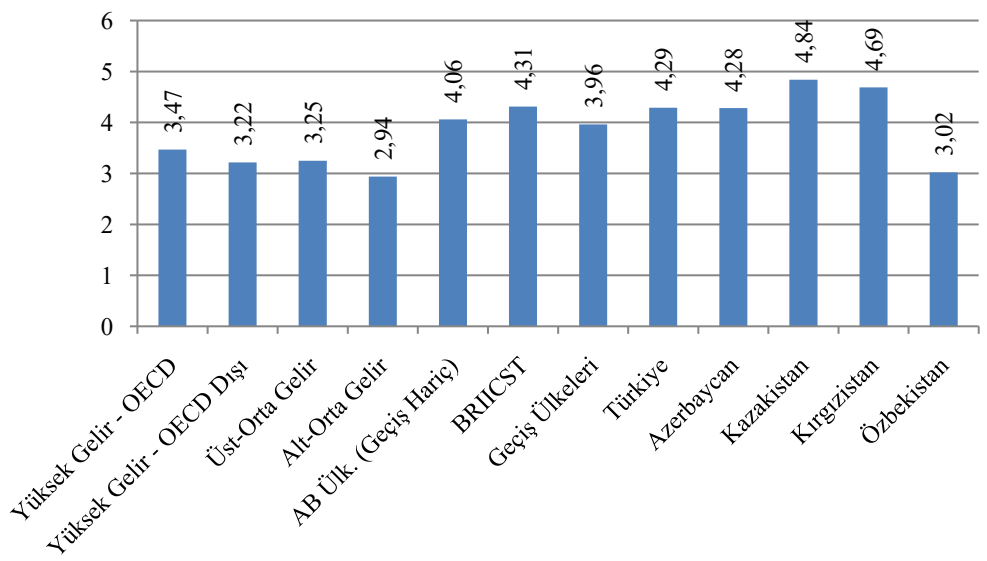

\section{Şekil 12. Orta Asya ve Türkiye'de Rekabet Dair Tutumlar}

Şekil 12, rekabete dair tutumları Orta Asya, Türkiye ve diğer ülke grupları ile karşılaştırmaktadır. Buna göre Özbekistan OAT arasında, rekabete dair olumlu tutumları yansıtan en düşük değere sahip olan ülkedir. Bu açıdan Özbekistan ortalaması OECD ve AB ülkelerinin de altındadır. Diğer OAT grubu ülkelerde ortalama geçiş ekonomileri ve gelişmekte olan ekonomiler ortalamalarına yakın olmakla birlikte özellikle Kazakistan ve Kırgızistan’da 
rekabete dair olumsuz görüşler ortalama olarak diğer ülkelerden ve ülke ortalamalarından yüksektir.

\section{Başarı ve servet birikimine dair tutumlar}

WVS/EVS bireylerin piyasanın işleyişi ve devletin rolü ile ilgili görüşlerini yansıtacak başka sorular da içermektedir. Ancak bunların çoğu ya az sayıda ülkede ve/veya sadece bazı dalgalarda sorulduğundan ülkeler arasında ya da zaman boyutunda kapsamlı bir karşılaştırma elde etmek mümkün olamamaktadır. Burada zaman boyutunda karşılaşıııma imkânı olmasa da Orta Asya ve Türkiye'yi WVS 6. dalgası kapsamında diğer ülke grupları ile karşılaştırma olanağı bulunan iki değişkeni daha inceleyeceğiz.

Bunlardan ilki, başarı ile çalışma arasındaki ilişkiye dair, diğeri servet birikimine dair görüşleri irdelemektedir. İlkinde başarının çok çalışmaya mı yoksa daha çok şansa, torpile vb. mi bağlı olduğuna (yüksek değer çalışarak başarı elde etmeye dair düşük inancı yansıtmaktadır) dair bireylerin görüşleri sorulmaktadır.
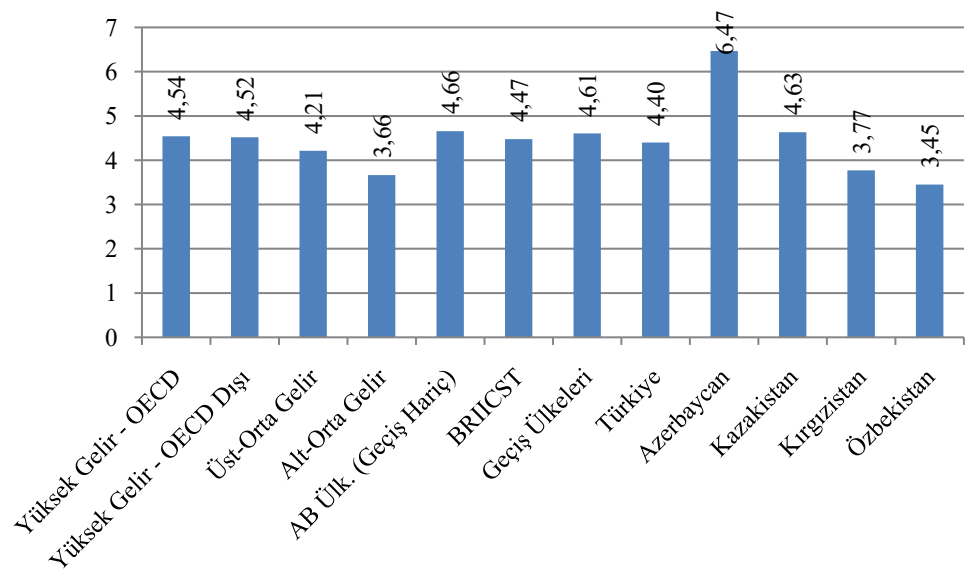

Şekil 13. Orta Asya ve Türkiye'de Çallş̧ma-Başar İlişkisine Dair Görü̈sler

Şekil 13 bu görüşler açısında Orta Asya ülkeleri ve Türkiye'yi diğer ülke grupları ile karşılaştırmaktadır. OAT grubu arasında çalışmaya başarı ile ilişkisi açısından en olumsuz yaklaşan ülke Azerbaycan'dır. Azerbaycan diğer ülke gruplarından da oldukça yüksek düzeyde başarıyı çalışma dışında şans, kayırma vb. faktörlerle ilişkilendirmektedir. Öteki yandan Özbekistan ve 
Kırgızistan başarıyı çalışmayla ilişkili görmek bakımından daha yüksek değerlere sahiptir.

Diğer soru bireylerin servet elde etmeyi sıfır toplamlı bir oyun olarak görüp görmediklerini değerlendirmeye yöneliktir. Buna göre zenginliğin ancak toplumdaki başka birinin aleyhine mi elde edilebileceği yoksa herkesin zengin olmasına yetecek kadar servetin herkes için var mı olduğunu düşündükleri sorulmuştur. Bu değişkenin bireylerin servet birikimi ve zenginliğe bakışını yansıtacağı düşünülebilir (daha yüksek değer servete karşı daha olumlu tutumu yansitmaktadır).

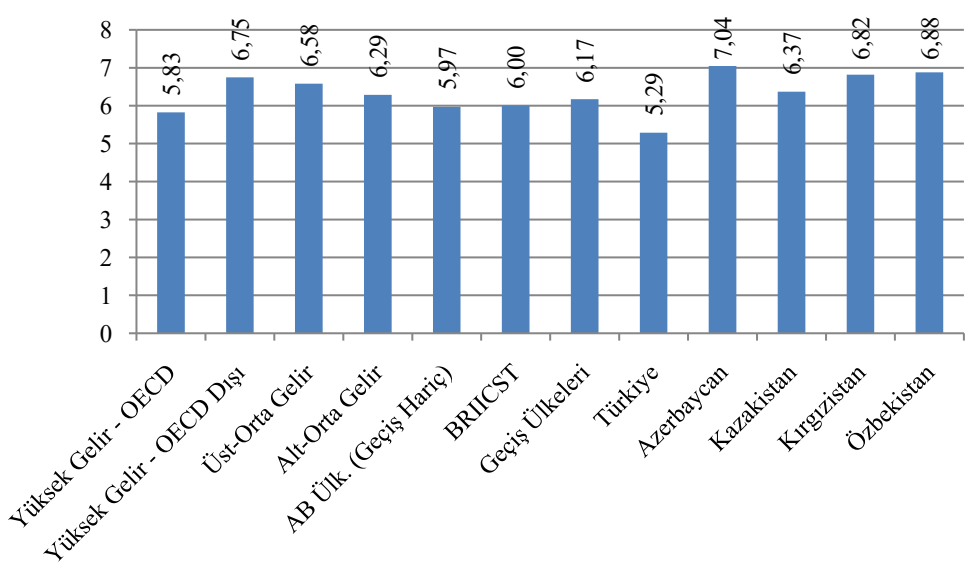

Şekil 14. Orta Asya ve Türkiye'de Servete Karşı Tutum

Şekil 14 bu soruya verilen cevapların ortalamalarını karşılaştırmaktadır. Genel olarak yüksek gelirli ülkelerde (OECD ve $A B)$ servete daha olumsuz bir tutum olduğu, diğer ülke gruplarına görece zenginliğin ancak toplumdaki diğer insanların aleyhine elde edilebileceğine dair görüşün daha yaygın olduğu görülmektedir. Türkiye şekilde gösterilen tüm ülke ve ülke grupları arasında bu anlamda ortalama olarak en olumsuz görüşe sahip ülkedir. Öte yandan Azerbaycan başta olmak üzere Orta Asya ülkeleri zenginliğe ve servet edinimine dair geçiş ekonomileri ve gelişmekte olan ülke ortalamalarından daha olumlu bir tutum sergilemektedir. 


\section{Bireysel Düzeyde Analiz: Orta Asya Ülkeleri ve Türkiye'de Yeniden Dağılım ve Mülkiyet Tercihlerinin Belirleyicileri}

Devletin ve piyasanın rolüne ilişkin tercihler ve devletin fonksiyon üstlenmesine ilişkin talepler ülke düzeyinde belirleyicilerle açıklanabileceği gibi bireysel faktörlere de bağlıdır. Bireylerin demografik özellikleri, ekonomik faktörler, devletle ve toplumla olan politik ve sosyal etkileşimleri bireylerin devletin rolüne dair tutumları üzerinde etkili olması beklenir.

Çalışmanın bu bölümünde devlet ve piyasaya dair görüşlerin en belirgin olduğunu varsaydığımız yeniden dağılım ve mülkiyete dair bireysel görüşlerin belirleyicilerini Orta Asya Ülkeleri ve Türkiye için incelenmektedir. İlgili literatüre de dayanarak, devletin rolüne dair görüşlerin temelde demografik faktörler, ekonomik faktörler ve bireylerin kollektif faaliyetlere tutumunu şekillendirecek sosyo-psikololojik faktörler tarafından belirleneceği varsayılmıştır. Bunları yansıtacak değişkenler WVS/EVS kapsamında toplanan verilerden derlenmiş olup OLS regresyonları ile incelenmiştir. EK-1 regresyon denklemlerinde kullanılan açıklayıcı değişkenlerin tam tanımlarını ve özet istatistiklerini sunmaktadır.

Demografi faktörler olarak; cinsiyet ( $1=$ kadın), yaş ve eğitim seviyesi regresyonlarda açılkayıcı değişken olarak ele alınmıştır.

Bireylerin ekonomik statüleri ve refah seviyelerinin devletin rolüne dair tutumları üzerinde etkili olması beklenir. Bu açıdan ekonomik faktörler olarak; istihdam durumu, gelir seviyesi, bireylerin sübjektif refahını gösteren mutluluk ve hayat tatmini seviyesi (Çevik 2016, Çevik ve Taşar 2016) açıklayıcı değişkenler olarak denklemlere dâhil edilmiştir.

Çok sayıda çalışma sosyal sermaye ve kolektif faaliyetlere katılımın hem ülkenin (Erdoğdu 2010) hem bireylerin ekonomik performansı ve devletle olan mali ilişkilerini belirleyici olduğunu ortaya koymaktadır (örneğin Bk. Çevik 2014). Bu açıdan sosyal sermaye ve kolektif faaliyetlere ilişkin bireysel tutumlar göstermek üzere; sosyal sermayenin göstergeleri olarak yaygın olarak kabul edilen genelleştirilmiş güven, hükümete güven, şirketlere güven ve ülkenin önceliğine dair görüşlerini yansıtan siyasal öncelik değişkenleri kullanıldı. 
Son olarak bireylerin siyasal eğilim ve görüşlerini temsil etmek üzere; otoriteye itaat eğilimleri ( $1=\mathrm{itaat})$, siyasal görü̈lleri (sol-sağ ayrımında 10 puanlık gösterge üzerinden), milliyetçilik düzeyleri, dindarlıkları (1=dindar) değerlendirilmiştir.

Birden fazla dalgada ölçüm bulunan Azerbaycan, Türkiye ve Kırgızistan için yıllar arasındaki farklılıkları kontrol altında tutmak için WVS/EVS dalgasını gösterir kukla değişkenler de denklemlere eklenmiştir.

Yeniden dağılıma ilişkin tercihlerin bireysel düzeyde belirleyicilerin OLS regresyonları aracılığıyla analizi Tablo-3’te sunulmaktadır. Buna göre önce Türkiye ve Orta Asya ülkelerinin tümünün dâhil olduğu örneklem yukarda anılan değişkenlerle analiz edilmiş (Sütun 1) sonra tek tek her ülke örneklemi için aynı denklem tekrar tahmin edilmiştir. Benzer prosedür Tablo-4'te mülkiyete dair tutumlar için de yinelenmiştir.

\section{Yeniden dağılım talebinin belirleyicileri}

Demografik değişkenlere bakıldığında, cinsiyet ülkeler arasında sadece Azerbaycan'da anlamlı bulunmuştur. Buna göre Azerbaycan'da kadın olmak erkeklere göre daha fazla yeniden dağılım tercihi ile birliktelik göstermektedir. Yaş, pozitif etkiye sahip gözükmektedir ve tüm örneklemde, Türkiye'de, Azerbaycan'da ve Özbekistan'da istatistiksel olarak anlamlıdır. Çocuk sayısı tüm örneklemde ve Kırgızistan'da istatistiksel olarak önemli ve negatif etkiye sahiptir. Eğitim seviyesi ise tüm örneklemde, Kazakistan'da ve Kırgızistan'da istatistiksel olarak anlamlıdır. Daha yüksek eğitim seviyesi gelir eşitsizliğini kabul edilir bulmak yönünde eğilimle birliktelik göstermektedir.

Ekonomik değişkenlere bakılırsa, istihdam durumunun çoğu durumda istatistiksel olarak anlamlı bir katsayı üretmediği görülmektedir. Tüm ülkelerin yer aldığ tahminde (Sütun 1) işsizlere görece tam zamanlı çalş̧anlar ve emekliler için istatistiksel olarak önemli ve pozitif katsayı bulunmuştur. Öte yandan gelir Özbekistan haricinde tüm tahminlerde anlamlı ve negatif katsayılı bulunmuştur. Buna göre gelir seviyesi artarken gelir eşitsizliklerinin giderilmesine ilişkin destek azalmaktadır. Sübjektif refah algısı temsil etmek üzere denklemlere dâhil edilen mutluluk ve hayat tatmini de gelir seviyesine benzer şekilde negatif katsayılıdır. Böylece gelir düzeyi ve sübjektif refah düzeyindeki artışların yeniden dağılıma olan destekte azalma ile birliktelik gösterdiği söylenebilir. 
Tablo 3. Yeniden Dağzlım Talebi: OLS Regresyon

\begin{tabular}{|c|c|c|c|c|c|c|}
\hline & (1) & (2) & (3) & (4) & (5) & (6) \\
\hline & $\begin{array}{c}\text { Orta Asya ve } \\
\text { Türkiye }\end{array}$ & Türkiye & Azerbay can & Kazakistan & Kurgzistan & Özbekistan \\
\hline Cinsiyet $(\mathrm{Kad} \ln =1)$ & $\begin{array}{r}0.054 \\
(-0.07)\end{array}$ & $\begin{array}{c}0.108 \\
(-0.12)\end{array}$ & $\begin{array}{l}0.272^{*} \\
(-0.15)\end{array}$ & $\begin{array}{r}0.085 \\
(-0.16)\end{array}$ & $\begin{array}{c}0.063 \\
(-0.14)\end{array}$ & $\begin{array}{r}0.102 \\
(-0.32)\end{array}$ \\
\hline Yaş & $\begin{array}{r}0.008 * * * \\
(0.00)\end{array}$ & $\begin{array}{r}0.009 \text { ** } \\
(0.00)\end{array}$ & $\begin{array}{l}0.013^{*} \\
(-0.01)\end{array}$ & $\begin{array}{r}0.008 \\
(-0.01)\end{array}$ & $\begin{array}{l}-0.001 \\
(-0.01)\end{array}$ & $\begin{array}{l}0.030 * \\
(-0.02)\end{array}$ \\
\hline Çocuk say isı & $\begin{array}{r}-0.080^{* * * *} \\
(-0.02)\end{array}$ & $\begin{array}{l}-0.008 \\
(-0.03)\end{array}$ & $\begin{array}{l}-0.073 \\
(-0.06)\end{array}$ & $\begin{array}{r}0.045 \\
(-0.06)\end{array}$ & $\begin{array}{r}-0.087^{*} \\
(-0.04)\end{array}$ & $\begin{array}{l}-0.182 \\
(-0.11)\end{array}$ \\
\hline Eğitim & $\begin{array}{r}-0.098 * * * * \\
(-0.02)\end{array}$ & $\begin{array}{l}-0.022 \\
(-0.02)\end{array}$ & $\begin{array}{r}0.01 \\
(-0.04)\end{array}$ & $\begin{array}{r}-0.131 * * * \\
(-0.04)\end{array}$ & $\begin{array}{r}-0.076^{* *} \\
(-0.04)\end{array}$ & $\begin{array}{r}0.125 \\
(-0.10)\end{array}$ \\
\hline \multicolumn{7}{|c|}{ İstihdam durumu (base: işsiz) } \\
\hline Tam zamanlı & $\begin{array}{r}0.255^{* * *} \\
(-0.11)\end{array}$ & $\begin{array}{r}0.052 \\
(-0.18)\end{array}$ & $\begin{array}{r}0.263 \\
(-0.22)\end{array}$ & $\begin{array}{l}-0.312 \\
(-0.32)\end{array}$ & $\begin{array}{r}0.11 \\
(-0.23)\end{array}$ & $\begin{array}{r}0.44 \\
(-0.50)\end{array}$ \\
\hline Kismi zamanli & $\begin{array}{l}-0.141 \\
(-0.13)\end{array}$ & $\begin{array}{r}0.378 \\
(-0.23)\end{array}$ & $\begin{array}{r}0.087 \\
(-0.28)\end{array}$ & $\begin{array}{r}-1.502 * * * \\
(-0.36)\end{array}$ & $\begin{array}{r}-0.617 * * \\
(-0.26)\end{array}$ & $\begin{array}{l}-0.059 \\
(-0.56)\end{array}$ \\
\hline Serbest meslek & $\begin{array}{l}-0.038 \\
(-0.13)\end{array}$ & $\begin{array}{r}-0.088 \\
(-0.2)\end{array}$ & $\begin{array}{r}0.102 \\
(-0.32)\end{array}$ & $\begin{array}{r}-1.920 * * * \\
(-0.44)\end{array}$ & $\begin{array}{r}0.12 \\
(-0.26)\end{array}$ & $\begin{array}{l}-0.346 \\
(-0.60)\end{array}$ \\
\hline Emekli & $\begin{array}{r}0.306^{* * *} \\
(-0.15)\end{array}$ & $\begin{array}{r}0.117 \\
(-0.24)\end{array}$ & $\begin{array}{r}0.014 \\
(-0.37)\end{array}$ & $\begin{array}{l}-0.482 \\
(-0.42)\end{array}$ & $\begin{array}{c}0.385 \\
(-0.33)\end{array}$ & $\begin{array}{l}0.018 \\
(-0.7)\end{array}$ \\
\hline Evhanımı & $\begin{array}{l}-0.081 \\
(-0.12)\end{array}$ & $\begin{array}{l}-0.151 \\
(-0.20)\end{array}$ & $\begin{array}{l}-0.341 \\
(-0.30)\end{array}$ & $\begin{array}{r}-0.909 * * \\
(-0.37)\end{array}$ & $\begin{array}{r}-0.425^{*} \\
(-0.25)\end{array}$ & $\begin{array}{l}-0.379 \\
(-0.57)\end{array}$ \\
\hline Öğrenci & $\begin{array}{r}0.102 \\
(-0.15)\end{array}$ & $\begin{array}{l}-0.229 \\
(-0.25)\end{array}$ & $\begin{array}{r}0.636^{* *} \\
(-0.32)\end{array}$ & $\begin{array}{l}-0.644 \\
(-0.46)\end{array}$ & $\begin{array}{l}-0.282 \\
(-0.30)\end{array}$ & $\begin{array}{r}1.685^{* *} \\
(-0.77)\end{array}$ \\
\hline Diğer & $\begin{array}{l}-0.053 \\
(-0.29)\end{array}$ & $\begin{array}{c}-0.13 \\
(-0.40)\end{array}$ & $\begin{array}{r}0.942 \\
(-0.85)\end{array}$ & $\begin{array}{r}0.427 \\
(-1.27)\end{array}$ & $\begin{array}{l}-0.148 \\
(-0.52)\end{array}$ & $\begin{array}{r}0.124 \\
(-2.99)\end{array}$ \\
\hline Gelir & $\begin{array}{r}-0.099 * * * \\
(-0.02)\end{array}$ & $\begin{array}{r}-0.126 * * * \\
(-0.02)\end{array}$ & $\begin{array}{r}-0.200 * * * \\
(-0.05)\end{array}$ & $\begin{array}{r}-0.202 * * * \\
(-0.04)\end{array}$ & $\begin{array}{r}-0.069^{*} \\
(-0.04)\end{array}$ & $\begin{array}{l}-0.057 \\
(-0.09)\end{array}$ \\
\hline Mutluluk & $\begin{array}{l}-0.024 \\
(-0.04)\end{array}$ & $\begin{array}{l}0.101^{*} \\
(-0.06)\end{array}$ & $\begin{array}{r}-0.224 * \\
(-0.12)\end{array}$ & $\begin{array}{l}-0.198 \\
(-0.13)\end{array}$ & $\begin{array}{r}-0.318^{* * * *} \\
(-0.12)\end{array}$ & $\begin{array}{r}0.236 \\
(-0.29)\end{array}$ \\
\hline Hayat tatmini & $\begin{array}{r}-0.064 * * * * \\
(-0.01)\end{array}$ & $\begin{array}{r}-0.100^{* * * *} \\
(-0.02)\end{array}$ & $\begin{array}{l}-0.002 \\
(-0.04)\end{array}$ & $\begin{array}{r}-0.074^{*} \\
(-0.04)\end{array}$ & $\begin{array}{r}0.007 \\
(-0.03)\end{array}$ & $\begin{array}{r}-0.149^{*} \\
(-0.09)\end{array}$ \\
\hline Genelleştirilmiş güven & $\begin{array}{r}0.147 * * \\
(-0.07)\end{array}$ & $\begin{array}{r}0.144 \\
(-0.13)\end{array}$ & $\begin{array}{r}0.18 \\
(-0.18)\end{array}$ & $\begin{array}{r}0.660 * * * \\
(-0.15)\end{array}$ & $\begin{array}{r}0.057 \\
(-0.14)\end{array}$ & $\begin{array}{r}0.859 * * \\
(-0.42)\end{array}$ \\
\hline Hükümete güven & $\begin{array}{l}-0.047 \\
(-0.03)\end{array}$ & $\begin{array}{r}-0.085 * * \\
(-0.04)\end{array}$ & $\begin{array}{r}-0.201 * * \\
(-0.09)\end{array}$ & $\begin{array}{l}-0.062 \\
(-0.09)\end{array}$ & $\begin{array}{r}0.252^{* * * *} \\
(-0.08)\end{array}$ & $\begin{array}{l}-0.316 \\
(-0.30)\end{array}$ \\
\hline Şirket gïven & $\begin{array}{r}-0.113^{* * * *} \\
(-0.03)\end{array}$ & $\begin{array}{r}-0.191^{* * *} \\
(-0.05)\end{array}$ & $\begin{array}{r}-0.214^{* * * *} \\
(-0.08)\end{array}$ & $\begin{array}{r}-0.164^{*} \\
(-0.10)\end{array}$ & $\begin{array}{l}-0.005 \\
(-0.08)\end{array}$ & $\begin{array}{l}-0.032 \\
(-0.17)\end{array}$ \\
\hline \multicolumn{7}{|c|}{ Kamusal mal önceliği: base ekonomik büyüme } \\
\hline Savunma & $\begin{array}{r}-0.136^{*} \\
(-0.08)\end{array}$ & $\begin{array}{l}-0.077 \\
(-0.12)\end{array}$ & $\begin{array}{r}0.003 \\
(-0.17)\end{array}$ & $\begin{array}{r}0.314 \\
(-0.26)\end{array}$ & $\begin{array}{r}-0.474 * * \\
(-0.21)\end{array}$ & $\begin{array}{l}-0.617 \\
(-0.42)\end{array}$ \\
\hline Özgürlük & $\begin{array}{l}-0.133 \\
(-0.09)\end{array}$ & $\begin{array}{l}-0.076 \\
(-0.14)\end{array}$ & $\begin{array}{l}-0.096 \\
(-0.21)\end{array}$ & $\begin{array}{r}-0.541^{* * * *} \\
(-0.20)\end{array}$ & $\begin{array}{r}0.08 \\
(-0.20)\end{array}$ & $\begin{array}{l}-0.133 \\
(-0.39)\end{array}$ \\
\hline Bay indırlık & $\begin{array}{r}-0.290 * * * * \\
(-0.11)\end{array}$ & $\begin{array}{r}-0.335 * * \\
(-0.14)\end{array}$ & $\begin{array}{r}0.424 \\
(-0.29)\end{array}$ & $\begin{array}{r}-0.860 * * \\
(-0.36)\end{array}$ & $\begin{array}{l}-0.004 \\
(-0.32)\end{array}$ & $\begin{array}{r}2.136^{* * *} \\
(-1.08)\end{array}$ \\
\hline Otoriteye itaat & $\begin{array}{r}-0.179 * * * 6 \\
(-0.06)\end{array}$ & $\begin{array}{r}-0.279 * * * * \\
(-0.09)\end{array}$ & $\begin{array}{l}-0.107 \\
(-0.20)\end{array}$ & $\begin{array}{l}-0.092 \\
(-0.15)\end{array}$ & $\begin{array}{c}0.021 \\
(-0.13)\end{array}$ & $\begin{array}{r}0.985 * * * \\
(-0.32)\end{array}$ \\
\hline Siyasal görüş & $\begin{array}{r}-0.100 * * * \\
(-0.01)\end{array}$ & $\begin{array}{r}-0.076 * * * * \\
(-0.02)\end{array}$ & $\begin{array}{l}-0.035 \\
(-0.03)\end{array}$ & $\begin{array}{l}-0.054 \\
(-0.03)\end{array}$ & $\begin{array}{r}-0.142 * * * \\
(-0.03)\end{array}$ & $\begin{array}{l}-0.077 \\
(-0.07)\end{array}$ \\
\hline Milliyetçilik & $\begin{array}{r}-0.074 * \\
(-0.04)\end{array}$ & $\begin{array}{r}-0.309^{*} * * * \\
(-0.07)\end{array}$ & $\begin{array}{r}0.529^{* * *} * \\
(-0.11)\end{array}$ & $\begin{array}{r}-0.426 * * * k \\
(-0.12)\end{array}$ & $\begin{array}{l}-0.051 \\
(-0.09)\end{array}$ & $\begin{array}{l}0.876^{*} \\
(-0.45)\end{array}$ \\
\hline Dindarlık & $\begin{array}{r}0.139 * * \\
(-0.07)\end{array}$ & $\begin{array}{r}-0.17 \\
(-0.11)\end{array}$ & $\begin{array}{r}1.017 * * * \\
(-0.17)\end{array}$ & $\begin{array}{r}0.228 \\
(-0.15)\end{array}$ & $\begin{array}{l}-0.047 \\
(-0.19)\end{array}$ & $\begin{array}{r}1.068 * \% * \\
(-0.29)\end{array}$ \\
\hline WVS/EVS Dalga & Evet & Evet & Evet & - & Evet & - \\
\hline 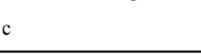 & $\begin{array}{r}8.543 * * * \\
(-0.27) \\
\end{array}$ & $\begin{array}{r}9.353 \text { **** } \\
(-0.37) \\
\end{array}$ & $\begin{array}{r}4.833 * * * \\
(-0.65) \\
\end{array}$ & $\begin{array}{r}11.006^{* * * *} \\
(-0.78) \\
\end{array}$ & $\begin{array}{r}8.120 * * * * \\
(-0.60) \\
\end{array}$ & $\begin{array}{r}2.96 \\
(-2.20) \\
\end{array}$ \\
\hline $\mathrm{R}^{2}$ & 0.04 & 0.05 & 0.07 & 0.13 & 0.06 & 0.13 \\
\hline $\mathrm{N}$ & 11804 & 5829 & 1773 & 1491 & 2217 & 494 \\
\hline
\end{tabular}

Sosyal sermayenin yaygın göstergesi olarak kullanılan genel güven seviyesi tüm örneklemde, Kazakistan'da ve Özbekistan'da istatistiksel olarak anlamlı ve pozitif katsayıya sahiptir. Böylece toplumdaki diğer bireylere olan güven artarken gelir eşitsizliklerinin giderilmesine ilişkin destek de artmaktadır. Ülkeler arasında işareti farklı bulgulardan biri hükümete güven'de elde edilmiştir. Hükümete güven Türkiye'de ve Azerbaycan'da yeniden dağglıma des- 
tekle negatif ilişki sergilerken, Kırgızistan'da oldukça kuvvetli ve pozitif bir ilişki göstermektedir. Özel sektöre güven beklenebileceği gibi yeniden dağllıma destekle negatif birlikteliğe sahiptir ve tüm örneklemde, Türkiye'de, Azerbaycan'da ve Kazakistan'da istatistiksel olarak anlamlı katsayıya sahiptir. Kamusal mallara ilişkin öncelikler ekonomik büyümeye görece diğer kategoriler de çoğunlukla negatif katsayıya sahiptir.

Siyasal görüş ve psikolojiye ilişkin olarak ise otoriteye itaat eğilimi ve siyasal görüşte sağ eğilimli olmak yeniden dağıtımı destekleyici tercihle negatif, dindarlık pozitif birliktelik göstermiştir. Milliyetçi olmak tüm örneklemde, Türkiye'de ve Kazakistan'da negatifken, Azerbaycan ve Özbekistan'da pozitif birliktelik göstermiştir. Buna karşın bu değişkenler tüm örneklemde istatistiksel olarak anlamlı iken, bunun dışında otoriteye itaat eğilimi tüm örneklemde, Türkiye'de ve Özbekistan'da; siyasal görüş Türkiye ve Kırgızistan'da, milliyetçilik Kırgızistan hariç diğer ülkelerde ve dindarlık tüm örneklemde, Azerbaycan'da ve Özbekistan'da istatistiksel olarak anlamlı bulunmuştur.

\section{Mülkiyete dair tercihlerin belirleyicileri}

Demografik değişkenlerden cinsiyet tüm örneklemde, Türkiye'de ve Kırg1zistan'da istatistiksel olarak anlamlı ve kamu mülkiyeti yönünde tercihlerle pozitif ilişkili bulunmuştur. Yaş ise tüm örneklemde ve Türkiye'de negatif, Kazakistan'da negatif birlikteliğe sahip olarak bulunmuş olmakla birlikte katsayılar genelde düşüktür. Çocuk sayısı sadece tüm örneklem ve Türkiye'de istatistiksel olarak anlamlı fakat kamu mülkiyetine destekle pozitif ilişkili bulunmuştur. Eğitim de benzer şekilde sadece tüm örneklem ve Türkiye'de anlamlıdır ancak negatif katsayıya sahiptir.

İstihdam durumu Kırgızistan ve Özbekistan'da istatistiksel olarak anlamlı ilişki ortaya koymamıştır. İşsiz kategorisi ile karşılaştırıldığında istatistiksel olarak en anlamlı kategori serbest meslek sahibi olanlar olmuştur. Bu kategori tüm örneklemde, Türkiye'de, Azerbaycan'da ve Kazakistan'da kamu mülkiyetine olan destekle negatif birliktelik göstermektedir. Gelir seviyesi kamu mülkiyeti yönünde tercihle, Özbekistan haricinde diğer tüm örneklemlerde negatif ve mutluluk sadece Kazakistan ve Kırgızistan'da anlamlı ve negatif ilişkili bulunmuştur. Hayattan tatmin düzeyi üzerinde ülkelerin hiçbirinde istatistiksel olarak anlamlı bir katsayı bulunamamıştır. 
Tablo 4. Mülkiyet Tercibleri: OLS Regresyon

\begin{tabular}{|c|c|c|c|c|c|c|}
\hline & (1) & (2) & (3) & (4) & (5) & (6) \\
\hline & $\begin{array}{l}\text { Orta Asya ve } \\
\text { Türkiye } \\
\end{array}$ & Türkiye & Azerbaycan & Kazakistan & Kırgizistan & Özbekistan \\
\hline Cinsiyet & $\begin{array}{r}0.328^{* * *} \\
(-0.07)\end{array}$ & $\begin{array}{r}0.323 * * * \\
(-0.12)\end{array}$ & $\begin{array}{l}-0.038 \\
(-0.16)\end{array}$ & $\begin{array}{l}-0.193 \\
(-0.16)\end{array}$ & $\begin{array}{l}0.260^{*} \\
(-0.14)\end{array}$ & $\begin{array}{l}-0.086 \\
(-0.34)\end{array}$ \\
\hline Yaș & $\begin{array}{r}-0.005^{*} \\
(0.00)\end{array}$ & $\begin{array}{r}-0.020 * * * * \\
(0.00)\end{array}$ & $\begin{array}{r}0.001 \\
(-0.01)\end{array}$ & $\begin{array}{r}0.017 * * \\
(-0.01)\end{array}$ & $\begin{array}{l}-0.001 \\
(-0.01)\end{array}$ & $\begin{array}{r}0.03 \\
(-0.02)\end{array}$ \\
\hline Çocuk say $1 \mathbf{s} 1$ & $\begin{array}{r}0.086 * * * \\
(-0.02)\end{array}$ & $\begin{array}{r}0.149 * * * \\
(-0.03)\end{array}$ & $\begin{array}{r}0.065 \\
(-0.06)\end{array}$ & $\begin{array}{c}0.005 \\
(-0.06)\end{array}$ & $\begin{array}{r}0.063 \\
(-0.04)\end{array}$ & $\begin{array}{l}-0.096 \\
(-0.12)\end{array}$ \\
\hline Eğitim & $\begin{array}{r}-0.061 * * * * \\
(-0.02)\end{array}$ & $\begin{array}{r}-0.127 * * * * \\
(-0.02)\end{array}$ & $\begin{array}{r}0.004 \\
(-0.04)\end{array}$ & $\begin{array}{r}0.052 \\
(-0.04)\end{array}$ & $\begin{array}{l}-0.038 \\
(-0.04)\end{array}$ & $\begin{array}{r}0.054 \\
(-0.11)\end{array}$ \\
\hline \multicolumn{7}{|c|}{ İstihdam durumu (base: işsiz) } \\
\hline Tam zamanlı & $\begin{array}{l}-0.092 \\
(-0.11)\end{array}$ & $\begin{array}{l}-0.217 \\
(-0.18)\end{array}$ & $\begin{array}{l}-0.067 \\
(-0.22)\end{array}$ & $\begin{array}{l}-0.415 \\
(-0.31)\end{array}$ & $\begin{array}{r}0.101 \\
(-0.23)\end{array}$ & $\begin{array}{l}-0.283 \\
(-0.53)\end{array}$ \\
\hline Kısmi zamanlı & $\begin{array}{l}-0.149 \\
(-0.13)\end{array}$ & $\begin{array}{r}-0.475 * * \\
(-0.23)\end{array}$ & $\begin{array}{l}-0.106 \\
(-0.29)\end{array}$ & $\begin{array}{l}-0.434 \\
(-0.35)\end{array}$ & $\begin{array}{r}0.071 \\
(-0.26)\end{array}$ & $\begin{array}{r}0.145 \\
(-0.59)\end{array}$ \\
\hline Serbest meslek & $\begin{array}{r}-0.556^{* * * *} \\
(-0.13)\end{array}$ & $\begin{array}{r}-0.573 * * * * \\
(-0.20)\end{array}$ & $\begin{array}{r}-0.952 * * * \\
(-0.31)\end{array}$ & $\begin{array}{r}-1.145^{* * * *} \\
(-0.44)\end{array}$ & $\begin{array}{l}-0.373 \\
(-0.26)\end{array}$ & $\begin{array}{r}0.069 \\
(-0.63)\end{array}$ \\
\hline Emekli & $\begin{array}{r}0.024 \\
(-0.15)\end{array}$ & $\begin{array}{r}-0.428 * \\
(-0.23)\end{array}$ & $\begin{array}{r}0.505 \\
(-0.38)\end{array}$ & $\begin{array}{r}0.287 \\
(-0.42)\end{array}$ & $\begin{array}{r}0.021 \\
(-0.33)\end{array}$ & $\begin{array}{l}-0.237 \\
(-0.75)\end{array}$ \\
\hline Evhanımı & $\begin{array}{l}-0.156 \\
(-0.12)\end{array}$ & $\begin{array}{l}-0.286 \\
(-0.20)\end{array}$ & $\begin{array}{r}0.264 \\
(-0.30)\end{array}$ & $\begin{array}{l}-0.132 \\
(-0.37)\end{array}$ & $\begin{array}{r}-0.32 \\
(-0.25)\end{array}$ & $\begin{array}{r}0.69 \\
(-0.61)\end{array}$ \\
\hline Öğrenci & $\begin{array}{r}0.143 \\
(-0.15)\end{array}$ & $\begin{array}{l}-0.308 \\
(-0.25)\end{array}$ & $\begin{array}{r}0.890 * * * \\
(-0.32)\end{array}$ & $\begin{array}{r}0.574 \\
(-0.45)\end{array}$ & $\begin{array}{l}-0.235 \\
(-0.30)\end{array}$ & $\begin{array}{r}0.107 \\
(-0.83)\end{array}$ \\
\hline Diğer & $\begin{array}{l}-0.041 \\
(-0.29)\end{array}$ & $\begin{array}{l}-0.077 \\
(-0.40)\end{array}$ & $\begin{array}{l}1.576^{*} \\
(-0.87)\end{array}$ & $\begin{array}{c}1.052 \\
(-1.27)\end{array}$ & $\begin{array}{r}-1.315^{* * *} \\
(-0.52)\end{array}$ & $\begin{array}{l}5.695^{*} \\
(-3.26)\end{array}$ \\
\hline Gelir & $\begin{array}{r}-0.117 * * * \\
(-0.02)\end{array}$ & $\begin{array}{r}-0.142 * * * \\
(-0.02)\end{array}$ & $\begin{array}{r}-0.135 * * * \\
(-0.05)\end{array}$ & $\begin{array}{r}-0.108^{* * *} \\
(-0.04)\end{array}$ & $\begin{array}{l}0.071^{*} \\
(-0.04)\end{array}$ & $\begin{array}{r}-0.13 \\
(-0.10)\end{array}$ \\
\hline Mutluluk & $\begin{array}{r}-0.087 * * \\
(-0.04)\end{array}$ & $\begin{array}{r}0.02 \\
(-0.06)\end{array}$ & $\begin{array}{l}-0.126 \\
(-0.12)\end{array}$ & $\begin{array}{r}-0.364 * * * * \\
(-0.13)\end{array}$ & $\begin{array}{r}-0.208^{*} \\
(-0.12)\end{array}$ & $\begin{array}{l}-0.088 \\
(-0.31)\end{array}$ \\
\hline Hay at tatmini & $\begin{array}{r}0.017 \\
(-0.01)\end{array}$ & $\begin{array}{r}0.027 \\
(-0.02)\end{array}$ & $\begin{array}{l}-0.047 \\
(-0.04)\end{array}$ & $\begin{array}{r}0.01 \\
(-0.04)\end{array}$ & $\begin{array}{l}-0.044 \\
(-0.03)\end{array}$ & $\begin{array}{r}0.068 \\
(-0.10)\end{array}$ \\
\hline Genelleștirilmiş güven & $\begin{array}{r}0.049 \\
(-0.07)\end{array}$ & $\begin{array}{l}-0.135 \\
(-0.13)\end{array}$ & $\begin{array}{r}-0.309^{*} \\
(-0.18)\end{array}$ & $\begin{array}{l}0.271^{*} \\
(-0.15)\end{array}$ & $\begin{array}{l}-0.222 \\
(-0.14)\end{array}$ & $\begin{array}{l}-0.237 \\
(-0.45)\end{array}$ \\
\hline Hükümete güven & $\begin{array}{r}0.150 * * * \\
(-0.03)\end{array}$ & $\begin{array}{r}0.193 * * * * \\
(-0.04)\end{array}$ & $\begin{array}{r}0.068 \\
(-0.09)\end{array}$ & $\begin{array}{r}0.196^{* * *} \\
(-0.09)\end{array}$ & $\begin{array}{l}-0.086 \\
(-0.08)\end{array}$ & $\begin{array}{r}0.153 \\
(-0.32)\end{array}$ \\
\hline Şirket güven & $\begin{array}{r}-0.222 * * * \\
(-0.03)\end{array}$ & $\begin{array}{r}-0.173^{* * * *} \\
(-0.04)\end{array}$ & $\begin{array}{l}-0.051 \\
(-0.08)\end{array}$ & $\begin{array}{r}-0.207^{* *} \\
(-0.10)\end{array}$ & $\begin{array}{r}-0.292^{* * * *} \\
(-0.08)\end{array}$ & $\begin{array}{l}-0.268 \\
(-0.18)\end{array}$ \\
\hline \multicolumn{7}{|c|}{ Kamusal mal önceliği: base ekonomik büyüme } \\
\hline Savunma & $\begin{array}{l}0.137 * \\
(-0.08)\end{array}$ & $\begin{array}{r}0.14 \\
(-0.12)\end{array}$ & $\begin{array}{r}0.16 \\
(-0.17)\end{array}$ & $\begin{array}{l}-0.419 \\
(-0.26)\end{array}$ & $\begin{array}{r}0.726^{* * * *} * \\
(-0.21)\end{array}$ & $\begin{array}{l}-0.128 \\
(-0.45)\end{array}$ \\
\hline Özgürlük & $\begin{array}{r}0.242 * * * \\
(-0.09)\end{array}$ & $\begin{array}{r}0.114 \\
(-0.13)\end{array}$ & $\begin{array}{r}0.596 * * * \\
(-0.22)\end{array}$ & $\begin{array}{l}-0.069 \\
(-0.20)\end{array}$ & $\begin{array}{l}0.377^{*} \\
(-0.21)\end{array}$ & $\begin{array}{r}0.399 \\
(-0.42)\end{array}$ \\
\hline Bay indırlık & $\begin{array}{r}0.266^{* * *} \\
(-0.11)\end{array}$ & $\begin{array}{r}0.458 * * * * \\
(-0.14)\end{array}$ & $\begin{array}{l}-0.236 \\
(-0.30)\end{array}$ & $\begin{array}{r}-0.17 \\
(-0.36)\end{array}$ & $\begin{array}{r}0.196 \\
(-0.33)\end{array}$ & $\begin{array}{l}-1.812 \\
(-1.25)\end{array}$ \\
\hline Otoriteye itaat & $\begin{array}{r}0.085 \\
(-0.06)\end{array}$ & $\begin{array}{r}0.018 \\
(-0.09)\end{array}$ & $\begin{array}{l}-0.253 \\
(-0.20)\end{array}$ & $\begin{array}{l}-0.134 \\
(-0.15)\end{array}$ & $\begin{array}{l}-0.007 \\
(-0.13)\end{array}$ & $\begin{array}{l}-0.087 \\
(-0.35)\end{array}$ \\
\hline Siyasal görüș & $\begin{array}{r}-0.042^{* * * *} \\
(-0.01)\end{array}$ & $\begin{array}{r}-0.038^{* * *} \\
(-0.02)\end{array}$ & $\begin{array}{l}-0.048 \\
(-0.03)\end{array}$ & $\begin{array}{r}-0.112^{* * *} \cdot k^{-0.03)} \\
(-0.03)\end{array}$ & $\begin{array}{r}-0.085^{* * * * *} \\
(-0.03)\end{array}$ & $\begin{array}{r}0.203 * * * \\
(-0.07)\end{array}$ \\
\hline Milliy etçilik & $\begin{array}{r}-0.091 * * \\
(-0.04)\end{array}$ & $\begin{array}{c}-0.08 \\
(-0.07)\end{array}$ & $\begin{array}{l}-0.013 \\
(-0.11)\end{array}$ & $\begin{array}{l}-0.117 \\
(-0.12)\end{array}$ & $\begin{array}{r}0.137 \\
(-0.09)\end{array}$ & $\begin{array}{l}-0.036 \\
(-0.49)\end{array}$ \\
\hline Dindarlik & $\begin{array}{r}-0.02 \\
(-0.07)\end{array}$ & $\begin{array}{r}-0.336^{* * *} \\
(-0.1)\end{array}$ & $\begin{array}{r}-0.422 * * \\
(-0.18)\end{array}$ & $\begin{array}{r}0.164 \\
(-0.15)\end{array}$ & $\begin{array}{r}0.16 \\
(-0.19)\end{array}$ & $\begin{array}{r}-0.764 * * \\
(-0.31)\end{array}$ \\
\hline WVS/EVS Dalga & Evet & Evet & Evet & - & Evet & - \\
\hline 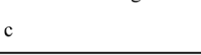 & $\begin{array}{r}7.259 * * * \\
(-0.27) \\
\end{array}$ & $\begin{array}{r}7.695 * * * \\
(-0.36) \\
\end{array}$ & $\begin{array}{r}7.041 * * * \\
(-0.66) \\
\end{array}$ & $\begin{array}{r}8.693 * * * \\
(-0.78) \\
\end{array}$ & $\begin{array}{r}6.990^{* * * *} \\
(-0.60)\end{array}$ & $\begin{array}{l}4.312 * \\
(-2.41) \\
\end{array}$ \\
\hline $\mathrm{R}^{2}$ & 0.04 & 0.07 & 0.06 & 0.08 & 0.04 & 0.06 \\
\hline $\mathrm{N}$ & 11816 & 5800 & 1810 & 1491 & 2210 & 505 \\
\hline
\end{tabular}

Genelleştirilmiş güven sadece Kazakistan'da anlamlı ve pozitif bir tahminci iken, beklenebileceği gibi hükümete güven pozitif, özel şirketlere güven negatif ilişkili bulunmuştur. Kamusal mallarda önceliklere ilişkin tercihler açısından bakıldığında ekonomik büyüme tercihine kıyasla diğer kategoriler pozitif katsayıa sahiptir. 
Otoriteye itaat eğilimi örneklemlerin hiçbirinde istatistiksel olarak anlamlı bir belirleyici olarak bulunmamıştır. Siyasal görüşte sağ eğilim arttıkça özel mülkiyete olan destek artmaktadır. Milliyetçilik sadece tüm örneklemde anlamlı ve negatif katsayılı olarak bulunmuştur. Dindarlık ise Türkiyede, Azerbaycan'da ve Özbekistan'da anlamlı kamu mülkiyetine destekle ile negatif ilişkili bulunmuştur.

\section{Sonuç}

Çalışma devletin rolüne ilişkin tutumlardaki farklılıkları ülkeler arasında karşılaştırmayı ve bireysel düzeyde yeniden dağılım ve kamu mülkiyetine dair tercihlerin belirleyicilerini Orta Asya Ülkeleri ve Türkiye için karşılaştırmalı olarak analiz etmeyi amaçlamıştır.

Ülkeler arasında karşılaştırma zaman boyutunda devletin rolü lehine eğilimin birçok ülke grubunda arttığını göstermektedir. Bir diğer önemli olgu devlet-piyasa karşıtllğı çerçevesindeki tutumların ülkelerin gelir seviyesi ile de ilişkili olduğudur. Yeniden dağılım yanlısı tutum kişi başı gelirle pozitif, kamu mülkiyeti, devlet sorumluluğu yanlısı görüşlerin negatif ilişkili olduğu bulunmuştur. Bir diğer eğilim ise bu görüşlerde ülke içinde homojenlik ülkede kişi başı gelir yükselirken artmaktadır.

Orta Asya ülkeleri ise devletin rolüne dair tutumlar bakımından heterojen görünüm sergilemektedir. Diğer geçiş ülkeleri ile karşılaştırıldığında yeniden dağılım açısından Özbekistan daha yüksek diğer Orta Asya ülkeleri daha düşük ortalamaya sahipken, kamu mülkiyeti yanlılığı açısından Kazakistan oldukça yüksek diğer Orta Asya ülkeleri geçiş ekonomilerine yakın değerlere sahiptir. Devlet sorumluluğu açısından is Azerbaycan'da ve Kırgızistan'da bireyin sorumluluğuna daha fazla ağırlık verilmektedir.

Bireysel tercihlerin belirleyicilerini incelemek üzere yürütülen regresyonlar çoğu demografik, sosyo-ekonomik, sosyal sermaye ve siyasal görüş/tercih değişkenleri için anlamlı fakat ülkeler arasında farklı sonuçlar üretmiştir. Yeniden dağılım tercihinin belirleyicileri açısından cinsiyet Azerbaycan dişında anlamlı bulunmamış, yaş ve eğitim bazı ülkelerde anlamlı ama katsayı açısından önemi düşük bulunmuştur. Gelir Kırgızistan haricinde istatistiksel olarak önemli ve katsayı itibariyle anlamlı bir değişkendir. Sübjektif refah göstergeleri olarak mutluluk ve hayat tatmini de bazı ülkeler için anlamlı 
sonuçlar üretmiştir. Sosyal sermaye göstergesi olarak güven Kazakistan ve Özbekistan'da açıklayıcı gücü yüksek tahmincilerdir. Öte yandan hükümete güven artışı (Kırgızistan hariç) ve şirketlere olan güven artışı daha düşük yeniden dağılım tercihi ile birliktelik göstermektedir. Bir diğer değişken olarak siyasal görüş Türkiye ve Kırgızistan için istatistiksel olarak anlamlıdır ve sağ görüşlülük yeniden dağılıma olan destekle negatif birliktelik göstermektedir. Milliyetçilik ülkeler arasında farklı etki göstermektedir: Türkiye ve Kazakistan'da negatif, Azerbaycan ve Özbekistan'da pozitif katsayıya sahiptir. Dindarlık açıklayıcı gücü yüksek bir değişkendir ve yeniden dağılıma olan destekle pozitif birliktelik göstermektedir.

Kamu mülkiyeti yanlısı tercihlerin belirleyicileri açısından bakıldığında cinsiyet Türkiye ve Kırgızistan'da istatistiksel olarak anlamlı ve önemli bir değişken, yaş yine bu iki ülkede istatistiksel olarak anlamlı fakat düşük katsayıya sahip ve eğitim düzeyi sadece Türkiye için anlamlı bulunmuştur. Gelir seviyesi Özbekistan hariç ülkelerde istatistiksel olarak anlamlı ve Kırgızistan hariç negatif katsayılıdır. Mutluluk Kazakistan ve Kırgızistan'da istatistiksel olarak anlamlı ve kamu mülkiyetine olan destekle negatif ilişkili bulunmuştur. Hayat tatmini hiçbir ülke için istatistiksel olarak anlamlı bir ilişki ortaya koymazken, genelleştirilmiş güven kamu mülkiyeti yanlısı tercihlerle Azerbaycan'da negatif, Kazakistan'da pozitif ilişkili bulunmuştur. Hükümete olan güven Türkiye ve Kazakistan için istatistiksel olarak anlamlı ve kamu mülkiyeti yanlısı tercihlerle pozitif ilişkilidir. Şirketlere güven açıklayıcı gücü önemli bir değişkendir ve artarken özel mülkiyet yanlısı tercihler artmaktadır. Kamu mülkiyeti tercihi ile otoriteye itaat eğilimi arasında istatistiksel olarak anlamlı bir ilişki bulunamamıştır. Ancak siyasal görüş Kırgızistan haricinde istatistiksel olarak önemli bir değişkendir ve Özbekistan harici ülkelerde sağ görüşlülük artarken özel mülkiyete olan destek artmaktadır. Milliyetçilik tüm örneklem dişında bireysel ülkelerde istatistiksel olarak anlamlı bir değişken değildir. Ancak dindarlık Türkiye, Azerbaycan ve Özbekistan'da anlamlı ve önemli bir değişkendir ve dindarlık artarken kamu mülkiyeti yanlısı tercihler azalmaktadır.

Çalışmanın en önemli kısıtlarından biri Orta Asya ülkelerinde verilerin sadece bir ya da birkaç dalgada toplanmış olmasıdır. Bu, yıllar itibariyle devletin rolüne ilişkin vatandaşların tercih ve taleplerindeki değişmenin ölçülmesini 
ve piyasa ekonomisine geçerken bu görüşlerin nasıl değiştiğinin izlenmesine imkân vermemektedir. Yine de en azından Türkiye ve kısmen Azerbaycan için bu değişim ayrı bir çalışmada ele alınabilir. Gelecek çalışmalar açısından, bu çalışmanın bulgularının sağlamlığını test etmek açısından farklı örneklemlerle ve nedenselliği dikkate alabilecek farklı istatistiksel yöntemlerle konunun tek tek ülkeler için de incelenmesi katkı sağlayıcı olacaktır.

\section{Açıklamalar}

1 Bu kapsamda değerlendirilen ülkeler: Brezilya, Rusya, Endonezya, Hindistan, Çin, Güney Afrika, Türkiye.

$2 \quad \mathrm{Bu}$ kapsamda değerlendirilen ülkeler: Arnavutluk, Azerbaycan, Beyaz Rusya, Bulgaristan, Çek Cumhuriyeti, Çin, Ermenistan, Estonya, Gürcistan, Hırvatistan, Kazakistan, Kırgızistan, Letonya, Litvanya, Macaristan, Makedonya, Moldova, Özbekistan, Polonya, Romanya, Rusya, Slovakya, Slovenya, Ukrayna, Vietnam.

\section{Kaynaklar}

Alesina, Alberto F. \& Paola Giuliano (2009). "Preferences for Redistribution". NBER Working Paper 14825.

Bergh, Andreas \& Christian Bjørnskov (2013). "Trust, Welfare States and Income Equality: What Causes What?”. IFN Working Paper No. 994.

Bjørnskov, Christian (2007). "Determinants of Generalized Trust: A CrossCountry Comparison". Public Choice 130: 1-21.

Blekesaune, Morten \& Jill Quadagno (2003). "Public Attitudes toward Welfare State Policies. A Comparative Analysis of 24 Nations". European Sociological Review 19: 415-427.

Çevik, Savaş (2010). "Geçiş Ekonomilerinde Kamu Maliyesi ve Mali Sistem Reformları”. Avrasya Etüdleri 16 (37): 77-100.

Çevik, Savaş (2014). "Tax Morale in Socio-Political Interactions: Insiders and Outsiders". Journal of Applied Business and Economics 16 (3): 101-115.

Çevik, Savaş (2016). "Kastamonu'nun Sübjektif Refahı: Mutluluğun Belirleyicileri Üzerine Bir İnceleme”. 1. Uluslararası Abana Sempozyumu Bildiriler Kitabı. 15-30.

Çevik, Savaş (2018). "Devletin Rolüne İlişkin Tercihlerin Belirleyicileri: Ülkeler Arası Karşılaştırma ve Türkiye”. International Journal of Public Finance 3 (1): 1-26.

Çevik, Savaş ve Erol Turan (2007). "Devletin Kurumsal Dönüşümü: Orta Asya Ülkeleri Perspektifinden”. Bilig: Türk Dünyası Sosyal Bilimler Dergisi 41: 205-224.

Çevik, Savaş ve M. Okan Taşar (2016). "Urban-Rural Differences in Subjective 
Well-being: Turkish Case”. 3rd ICSAE. 26-28 Eylül Warsaw, Poland.

Corneo, Giacomo \& Hans Peter Grüner (2002). "Individual Preferences for Political Redistribution”. Journal of Public Economics 83: 83-107.

Dallinger, Ursula (2010). "Public Support for Redistribution: What Explains Cross-national Differences?”. Journal of European Social Policy 20: 333-349.

Erdoğdu, M. Mustafa (2010). "Beşeri Gelişme Perspektifinden Türkiye’de Kamu Eğitim ve Sağlık Harcamaları”. İktisat Dergisi 513: 13-28.

EVS (2016). European Values Study 1981-2008, Longitudinal Data. GESIS Data Archive. https://dbk.gesis.org (Erişim Tarihi: 20.11.2016).

Feldman, Stanley \& Marco Steenbergen (2001). "The Humanitarian Foundation of Public Support for Social Welfare". American Journal of Political Science 45: 658-677.

Fong, Christina (2001). "Social Preferences, Self-Interest, and the Demand for Redistribution”. Journal of Public Economics 82: 225-246.

Jaeger, Mads Meier (2013). "The Effect of Macroeconomic and Social Conditions on the Demand for Redistribution: A Pseudo Panel Approach”. Journal of European Social Policy 23: 149-163.

Jakobsen, Tor Georg (2011). "Welfare Attitudes and Social Expenditure: Do Regimes Shape Public Opinion?”. Social Indicators Research 101: 323-340.

Koster, Ferry (2009). "Welfare State Attitudes and Economic Integration in the EU, 1992-2002: A Multilevel Investigation across 24 Countries". mimeo www.ferrykoster.nl (Erişim Tarihi: 20.11.2016).

Pitlik, Hans \& Ludek Kouba (2013). "The Interrelation of Informal Institutions and Governance Quality in Shaping Welfare State Attitudes”. For Europe Working Papers. 38. http://www.foreurope.eu (Erişim Tarihi: 25.11.2016).

Roosma, Femke, John Gelissen \& Wim van Oorschot (2013). “The Multidimensionality of Welfare State Attitudes: A European Cross-National Study”. Social Indicators Research 113 (1): 235-255.

Stegmüller, Daniel, Peer Scheepers, Sigrid Roßteuscher \& Eelke de Jong (2011). "Support for Redistribution in Western Europe. Assessing the Role of Religion”. European Sociological Review 28 (4): 482-497.

Svallfors, Stefan (2012). "Government Quality, Egalitarianism, and Attitudes to Taxes and Social Spending: A European Comparison”. European Political Science Review 4: 1-18.

WVS (2016). World Value Survey 1981-2014 Longitudinal Aggregate Data. World Values Survey Association (www.worldvaluessurvey.org). 
EK 1. Orta Asya ve Türkiye'ye İlişkin OLS Regresyonlara Dâhil Değişkenler: Tanım ve Özet İstatistik

\begin{tabular}{|c|c|c|}
\hline Değișken & Açıklama & Özet İstatistik $(*)$ \\
\hline \multirow{2}{*}{ Cinsiyet } & & Erkek: $\% 47,5$ \\
\hline & & Kadın: $\% 52,5$ \\
\hline Yaş & & $\begin{array}{l}\text { Ort: 37,70; Std. Hata: } \\
\text { 14,35;Min: 16;Maks: } 91\end{array}$ \\
\hline Çocuk sayısı & & $\begin{array}{l}\text { Ort: 2,07; Std. Hata: } \\
\text { 1,91; Min: 0; Maks: } 8\end{array}$ \\
\hline $\begin{array}{l}\text { Eğitim } \\
\text { seviyesi }\end{array}$ & $\begin{array}{l}\text { Temel eğitimden terk (1) ile üniversite } \\
\text { mezunu (8) arasında tamamlanan eğitim } \\
\text { seviyesi }\end{array}$ & $\begin{array}{l}\text { Ort: 4,67; Std. Hata: } \\
\text { 2.27; Min: 1; Maks: } 8\end{array}$ \\
\hline \multirow{8}{*}{$\begin{array}{l}\text { İstihdam } \\
\text { statüsü }\end{array}$} & \multirow{8}{*}{$\begin{array}{l}\text { Katılımcının işgücü sektöründeki pozis- } \\
\text { yonu. }\end{array}$} & Tam zamanl1: $\% 27,28$ \\
\hline & & Yarı zamanlı: \% 8,66 \\
\hline & & Serbest meslek: \%10,56 \\
\hline & & Emekli: \% 9,12 \\
\hline & & Evhanımı: \% 25,46 \\
\hline & & Öğrenci: \% 6, 98 \\
\hline & & İşsiz: \% 10,30 \\
\hline & & Diğer: \% 1 \\
\hline Gelir düzeyi & $\begin{array}{l}1 \text { En düşük ve } 10 \text { en yüksek düzeyi gös- } \\
\text { termek üzere hanehalkının yıllık geliri }\end{array}$ & $\begin{array}{l}\text { Ort: 4,15; Std. Hata: } \\
\text { 2.05; Min: } 1 \text {; Maks: } 10\end{array}$ \\
\hline Mutluluk & $\begin{array}{l}\text { "Bir bütün olarak değerlendirdiğinizde } \\
\text { kendinizi ne kadar mutlu hissediyor- } \\
\text { sunuz?" sorusuna 1-hiç mutlu değil ve } \\
\text { 4-çok mutlu şeklinde verilen cevaplar } \\
\text { (orijinal cevaplar ters kodlanmıştır) }\end{array}$ & $\begin{array}{l}\text { Ort: 3,09 Std. Hata: 0,79; } \\
\text { Min: 1; Maks: } 4\end{array}$ \\
\hline $\begin{array}{l}\text { Hayattan } \\
\text { tatmin }\end{array}$ & $\begin{array}{l}\text { "Hayatınızdan ne derece tatminsiniz?" } \\
\text { sorusuna 1-hiç tatmin değilim ve } 10 \text {-çok } \\
\text { tatminim şeklinde verilen cevaplar. }\end{array}$ & $\begin{array}{l}\text { Ort: 6,45; Std. Hata: } \\
\text { 2,56; Min: 1; Maks: } 10\end{array}$ \\
\hline \multirow{2}{*}{$\begin{array}{l}\text { Genelleştiril- } \\
\text { miş güven }\end{array}$} & \multirow{2}{*}{$\begin{array}{l}\text { "Sizce genelde insanların çoğunluğuna } \\
\text { güvenilebilir mi? Yoksa başkalarıyla bir } \\
\text { ilişki kurarken veya iş yaparken çok dik- } \\
\text { katli olmak mı gerekir?" sorusuna verilen } \\
\text { cevaplar. }\end{array}$} & Güvenilebilir: \%18,16 \\
\hline & & $\begin{array}{l}\text { Dikkatli olunmalı: } \\
\% 79,73\end{array}$ \\
\hline
\end{tabular}




\begin{tabular}{|c|c|c|}
\hline $\begin{array}{l}\text { Hükümete } \\
\text { güven }\end{array}$ & $\begin{array}{l}\text { "Aşağıldakilere ne kadar güven hissedi- } \\
\text { yorsunuz?: Hükümet" sorusuna 1-Hiç } \\
\text { güvenmiyorum ve 4-Çok güveniyorum } \\
\text { şeklinde verilmiş cevaplar (orijinal cevap- } \\
\text { lar ters kodlanmıştır). }\end{array}$ & $\begin{array}{l}\text { Ort: 2,69; Std. Hata: } \\
\text { 1,06; Min: 1; Maks: } 4\end{array}$ \\
\hline $\begin{array}{l}\text { Şirketlere } \\
\text { güven }\end{array}$ & $\begin{array}{l}\text { "Aşağıdakilere ne kadar güven hissedi- } \\
\text { yorsunuz?: Büyük şirketler" sorusuna } \\
\text { 1-Hiç güvenmiyorum ve 4-Çok güveni- } \\
\text { yorum şeklinde verilmiş cevaplar (orijinal } \\
\text { cevaplar ters kodlanmıştır). }\end{array}$ & $\begin{array}{l}\text { Ort: 2,48; Std. Hata: } \\
\text { 0,95; Min: 1; Maks: } 4\end{array}$ \\
\hline $\begin{array}{l}\text { Siyasal ön- } \\
\text { celik }\end{array}$ & $\begin{array}{l}\text { Kolektif mallar konusunda bireyin önce- } \\
\text { liğini yansıtmak üzere "Ülkenin ilk hedefi } \\
\text { sizce ne olmalıdır" şeklinde soruya veri- } \\
\text { len "yüksek kalkınma hızı", "güçlü bir sa- } \\
\text { vunma kuvveti", "bireylerin söz hakkına } \\
\text { sahip olması" ve "sşehirlerin ve köylerin } \\
\text { güzelleştirilmesi" şeklindeki cevaplardan } \\
\text { ilk ikisi "güvenlik" son ikisi "özgürlük" } \\
\text { olarak yeniden kodlanmak suretiyle kukla } \\
\text { değişken oluşturulmuştur. }\end{array}$ & $\begin{array}{l}\text { Ekonomi: \% 50,25 } \\
\text { Güvenlik: \%11,00 } \\
\text { Özgürlük: \%8,72 } \\
\text { Bayındırlı: } \% 6,03\end{array}$ \\
\hline $\begin{array}{l}\text { Otoriteye } \\
\text { itaat }\end{array}$ & $\begin{array}{l}\text { Otoriteye karşı tutuma vekâlet etmek } \\
\text { üzere "Sizce çocukların evde ögrenmesi } \\
\text { gerekenler şeyler hangileridir, aşağıdaki- } \\
\text { lerden } 5 \text { tanesini seçiniz" sorusuna "itaat" } \\
\text { seçeneğinin önemli bulunup bulunmadığ1- } \\
\text { n1 değerlendiren cevaplar. }\end{array}$ & $\begin{array}{l}\text { İtaat - anılmadı: \%60,98 } \\
\text { İtaat - önemli: } \% 32,14\end{array}$ \\
\hline $\begin{array}{l}\text { Siyasal gö- } \\
\text { rüş }\end{array}$ & $\begin{array}{l}\text { "Siyasi konularda "sol"dan ve "sağ"dan } \\
\text { bahsedildiğini sık sık duyuyoruz. "I" en } \\
\text { solu, "10” ise en sağl göstermek üzere } \\
\text { kendinizin siyasal görüşünü bu cetvelde } \\
\text { nerede görüyorsunuz?" sorusuna verilen } \\
\text { cevap. }\end{array}$ & $\begin{array}{l}\text { Ort: 5,80; Std. Hata: } \\
\text { 2,52; Min: 1; Maks: } 10\end{array}$ \\
\hline Milliyetçilik & $\begin{array}{l}\text { "Türk olmaktan ne kadar gurur duyuyor- } \\
\text { sunuz?" sorusuna 1-Hiç gurur duymuyo- } \\
\text { rum; 4-Çok gurur duyuyorum şeklinde } \\
\text { verilen cevaplar (orijinal cevaplar ters } \\
\text { kodlanmiştır). }\end{array}$ & $\begin{array}{l}\text { Ort: } 3,58 ; \text { Std. Hata: } \\
\text { 0,71; Min: 1; Maks: } 4\end{array}$ \\
\hline Dindarlık & $\begin{array}{l}\text { “Kendinizi dindar bir kişi olarak mı } \\
\text { görürsünüz?" sorusuna verilen cevaplar } \\
\text { 1-Dindar 2- Dindar değil olarak yeniden } \\
\text { kodlanmıştır. }\end{array}$ & $\begin{array}{l}\text { Dindar: \%74, } 09 \\
\text { Dindar değil: \%21,78 }\end{array}$ \\
\hline
\end{tabular}

(*) Yüzde, ortalama ve standart hata olarak verilen özet istatistikler tüm ülkeler dâhil örnekleme ilişkindir. Analizde kullanılan değişkenlerin gözlem sayısına bağlı olarak analize dâhil gözlemlerle farklılık gösterebilir. 


\title{
Attitudes toward the Role of Government in Central Asian Countries and Turkey ${ }^{*}$
}

\section{Savaş Çevik ${ }^{* *}$}

\begin{abstract}
The paper studies the differences in attitudes toward the role of the state among the countries and addresses empirically determinants of personal preferences on redistribution and public ownership of firms in Central Asia Countries and Turkey. In the study, we employed the data by World Value Survey (WVS) and European Value Survey (EVS). The comparison at country level indicates that pro-government preferences increase in the most of the countries by the time. Another fact is that the average of individualistic/collectivist attitudes is correlated with the per capita income level of countries. Attitudes favor of redistribution are positively correlated with per capita GDP, while attitudes favor public ownership and government responsibility are negatively correlated with it. Moreover, the homogeneity of citizens' views in a country is positively associated with the country's income level. We analyzed the individual-level determinants of the preferences on redistribution and ownership in Central Asian Countries and Turkey by both the country-level samples and a combined sample of mentioned countries. Results reveal the evidences on significance of income level, subjective wellbeing (happiness and life satisfaction), generalized trust, confidence on government and private sector firms, political views and religiousness in order to determine the preferences on redistribution and ownership, along with demographic characteristics such as gender, age. However, the significance and magnitude of coefficients vary to country sample.
\end{abstract}

Keywords

Redistribution, political preferences, welfare state, social trust, Central Asia, the role of the state.

\footnotetext{
Date of Arrival: 09 February 2017 - Date of Acceptance: 07 June 2017

You can refer to this article as follows :

Çevik, Savaş (2019). “Orta Asya Ülkelerinde ve Türkiye'de Devletin Rolüne İlişkin Tutumlar”. bilig Journal of Social Sciences of the Turkic World 91: 81-112.

** Assoc. Prof. Dr., Selçuk University, Faculty of Economics and Administrative Sciences Department of Economics - Konya/Turkey

ORCID ID: https://orcid.org/0000-0003-0730-0746

scevik@selcuk.edu.tr
} 


\title{
Отношение к роли правительства в странах Центральной Азии и Турции*
}

\author{
Саваш Чевик *
}

\begin{abstract}
Аннотация
В статье рассматриваются различия в отношении к роли государства и рассматриваются детерминанты личных предпочтений в отношении перераспределения и государственной собственности в странах Центральной Азии и Турции. В исследовании мы использовали данные World Value Survey (WVS) и European Value Survey (EVS). Сравнение на уровне страны показывает, что проправительственные предпочтения в большинстве стран возрастают с течением времени. Другим фактом является то, что средние величины личностного / коллективного отношения коррелирует с уровнем дохода на душу населения в странах. Отношение в пользу перераспределения положительно коррелирует с ВВП на душу населения, в то время как отношение в пользу государственной собственности и ответственности правительства отрицательно коррелирует с этим. Кроме того, однородность взглядов граждан в стране положительно связана с уровнем доходов страны. Мы проанализировали детерминанты индивидуального уровня предпочтений по перераспределению и собственности в странах Центральной Азии и Турции как по выборкам на уровне стран, так и по комбинированной выборке из упомянутых стран. Результаты свидетельствуют о значимости уровня дохода, субъективного благополучия (счастья и удовлетворенности жизнью), общего доверия, доверия к правительственным и частным компаниям, политических взглядов и религиозности в определении предпочтения в отношении перераспределения и собственности, наряду с важностью таких демографических характеристик как пол и возраст. Однако значимость и величина коэффициентов варьируются в зависимости от выборки страны.
\end{abstract}

\section{Ключевые слова}

перераспределение, политические предпочтения, государство всеобщего благосостояния, социальное доверие, Центральная Азия, роль государства

\footnotetext{
* Поступило в редакцию: 09 февраля 2017 г. - Принято в номер: 07 июня 2017 г. Ссылка на статью:

Çevik, Savaş (2019). “Orta Asya Ülkelerinde ve Türkiye'de Devletin Rolüne İlişkin Tutumlar”. bilig - Журнал Гуманитарных Наук Тюркского Мира 91: 81-112.

** Доц., д-р, Сельджукский университет, факультет экономики и управления, отделение управления - Конья / Турция ORCID ID: https://orcid.org/0000-0003-0730-0746 scevik@selcuk.edu.tr
} 